\title{
Tree-grass phenology information improves light use efficiency modelling of gross primary productivity for an Australian tropical savanna
}

\author{
Caitlin E. Moore ${ }^{1,2}$, Jason Beringer ${ }^{1,2}$, Bradley Evans ${ }^{3,4}$, Lindsay B. Hutley ${ }^{5}$, and Nigel J. Tapper ${ }^{1}$ \\ ${ }^{1}$ School of Earth, Atmosphere and Environment, Monash University, Clayton, VIC, 3800, Australia \\ ${ }^{2}$ School of Earth and Environment, University of Western Australia, Crawley, WA, 6009, Australia \\ ${ }^{3}$ Department of Environmental Sciences, University of Sydney, Eveleigh, NSW, 2015, Australia \\ ${ }^{4}$ Terrestrial Ecosystem Research Network Ecosystem Modelling and Scaling Infrastructure, University of Sydney, \\ Eveleigh, NSW, 2015, Australia \\ ${ }^{5}$ School of Environment, Research Institute for the Environment and Livelihoods, Charles Darwin University, \\ Casuarina, NT, 0909, Australia
}

Correspondence to: Caitlin E. Moore (caitlin@moorescience.com.au)

Received: 15 May 2016 - Published in Biogeosciences Discuss.: 30 May 2016

Revised: 1 December 2016 - Accepted: 16 December 2016 - Published: 10 January 2017

\begin{abstract}
The coexistence of trees and grasses in savanna ecosystems results in marked phenological dynamics that vary spatially and temporally with climate. Australian savannas comprise a complex variety of life forms and phenologies, from evergreen trees to annual/perennial grasses, producing a boom-bust seasonal pattern of productivity that follows the wet-dry seasonal rainfall cycle. As the climate changes into the 21 st century, modification to rainfall and temperature regimes in savannas is highly likely. There is a need to link phenology cycles of different species with productivity to understand how the tree-grass relationship may shift in response to climate change. This study investigated the relationship between productivity and phenology for trees and grasses in an Australian tropical savanna. Productivity, estimated from overstory (tree) and understory (grass) eddy covariance flux tower estimates of gross primary productivity (GPP), was compared against 2 years of repeat time-lapse digital photography (phenocams). We explored the phenology-productivity relationship at the ecosystem scale using Moderate Resolution Imaging Spectroradiometer (MODIS) vegetation indices and flux tower GPP. These data were obtained from the Howard Springs OzFlux/Fluxnet site (AU-How) in northern Australia. Two greenness indices were calculated from the phenocam images: the green chromatic coordinate (GCC) and excess green index (ExG).
\end{abstract}

These indices captured the temporal dynamics of the understory (grass) and overstory (trees) phenology and were correlated well with tower GPP for understory $\left(r^{2}=0.65\right.$ to 0.72$)$ but less so for the overstory $\left(r^{2}=0.14\right.$ to 0.23$)$. The MODIS enhanced vegetation index (EVI) correlated well with GPP at the ecosystem scale $\left(r^{2}=0.70\right)$. Lastly, we used GCC and EVI to parameterise a light use efficiency (LUE) model and found it to improve the estimates of GPP for the overstory, understory and ecosystem. We conclude that phenology is an important parameter to consider in estimating GPP from LUE models in savannas and that phenocams can provide important insights into the phenological variability of trees and grasses.

\section{Introduction}

Savanna ecosystems are defined by the coexistence of trees and grasses and have evolved to dominate one-fifth of the terrestrial land surface (Scholes and Archer, 1997; Grace et al., 2006). In tropical savanna, trees utilise the $C_{3}$ photosynthetic pathway, whereas the grasses more commonly use the $\mathrm{C}_{4}$ pathway, being more efficient at taking up carbon in hot environments with limited water and nutrient availability (Sage, 2004; Osborne and Beerling, 2006). Savannas are typ- 
ically found in wet-dry climates that over time have shaped the tree-grass structure and phenology seen today. Fire also plays a role in shaping savanna phenology and structure, with recurrences often every 1-5 years (Hoffmann et al., 2012; Beringer et al., 2015). Fire consumes cured grass biomass in the dry season and suppresses growth of juvenile overstory species, resulting in a range of plant phenology responses to deal with it (Bond, 2008; Murphy et al., 2010; Werner and Franklin, 2010). Herbivory, drought and land-use change are additional disturbances that commonly occur in savannas (Hutley and Beringer, 2011). These complex interactions are believed to be the primary reason for the co-dominance of trees and grasses in savanna ecosystems, as well as for the phenological variability displayed (Bond et al., 2003; Van Langevelde et al., 2003; Bond, 2008; Hanan and Lehmann, 2010; Lehmann et al., 2014).

The climate and disturbance regime in savannas plays an important role in shaping plant phenology. $\mathrm{C}_{4}$ savanna grasses typically follow a boom-bust phenological cycle, where they rapidly produce biomass in the wet season and display an annual or perennial die-back phenology in the dry season (Bond, 2008; Ratnam et al., 2011). C $_{3}$ savanna trees, in contrast, can range from having a fully deciduous phenology to remaining evergreen throughout the dry season. In Australian savannas, the understory is dominated by $\mathrm{C}_{4}$ annual grasses with a small portion represented by juvenile overstory species (Werner and Franklin, 2010; Werner and Prior, 2013) and perennial grasses. Evergreen eucalypt species make up the bulk $(\sim 80 \%)$ of the overstory in Australian savannas (Hutley et al., 2011), but semi-, brevi- and fully deciduous species are found to a lesser degree throughout (Williams et al., 1997) and contribute to the seasonal fluctuation of canopy leaf area (O'Grady et al., 2000; Whitley et al., 2011). Tree : grass ratios are driven by annual rainfall, and in Australia there is a strong rainfall gradient from the coast inland (Rogers and Beringer, 2016), resulting in northern high rainfall (mesic) regions supporting higher tree: grass ratios and drier southern (xeric) regions supporting higher grass : tree ratios (Hutley et al., 2011; Ma et al., 2013).

The monitoring of savanna phenology can inform how savannas might respond to climate change. At the regional scale, the timing of phenological events varies widely for savannas due to variability in the occurrence and duration of rainfall events (Ma et al., 2013). Phenology, in turn, influences the productivity and growth (carbon cycle) of an ecosystem, as well as its water and nutrient cycles (Noormets, 2009; Richardson et al., 2013). The savanna region of Australia is projected to experience warming and increased rainfall (variability and amount) under climate change (Reisinger et al., 2014), which is likely to impact savanna phenology and its interactions with the carbon, nutrient and water cycles (Kanniah et al., 2010; Scheiter et al., 2015). There is a need for better understanding of what governs savanna phenology in order to predict how it may be affected by climate change (Beringer et al., 2016a).
Due to the large extent and spatial variation of savannas, satellite remote sensing provides a useful tool (Broich et al., 2015) for examining the interactions of savanna phenology with productivity. Vegetation indices such as the normalised difference vegetation index (NDVI) (Tucker, 1979) and enhanced vegetation index (EVI) (Huete et al., 2002) provide valuable measures of savanna phenological variability from the landscape to global scale (Ma et al., 2013, 2014). Likewise, the Moderate Resolution Imaging Spectroradiometer (MODIS) gross primary productivity (GPP) product (MOD17 A2; Running and Zhao, 2015) is a widely used means of estimating large-scale savanna productivity (Grace et al., 2006; Ryu et al., 2011), but it has been shown to underestimate savanna GPP, particularly during the transition between the wet and dry seasons (Kanniah et al., 2009; Whitley et al., 2011; Ma et al., 2014). The remoteness of satellite sensors from the ecosystems they measure, along with the effects of cloud contamination on daily data collection and the need to aggregate imagery spatially and temporally for contiguous scenes, results in coarse temporal resolution (i.e. 8 or 16 day) satellite data products that can be problematic for identifying change in seasonally cloudy tropical environments (Eberhardt et al., 2016) where rapid (i.e. 12 weeks) phenological change is common (Williams et al., 1997; Moore et al., 2016b).

A novel approach to alleviate some of the limitations of satellite remote sensing is to use in situ automated time-lapse cameras (phenocams) that can collect high temporal resolution (hourly to daily) images of vegetation within and above an ecosystem (Richardson et al., 2007; Hufkens et al., 2012; Sonnentag et al., 2012; Moore et al., 2016b). The proximity of these cameras to ecosystem vegetation allows them to capture important information about vegetation cover change, particularly that of leaf emergence and senescence (Richardson et al., 2007, 2009a; Wingate et al., 2015) that can be linked with measures of ecosystem GPP (Toomey et al., 2015; Richardson et al., 2010). Phenocam data have also been used for parameterising light use efficiency (LUE) models (in a similar way to MODIS GPP) that describe ecosystem GPP using absorbed photosynthetically active radiation (APAR) and plant LUE (Migliavacca et al., 2011).

In this study, we aim to contribute a detailed assessment of phenological change, and its relationship with productivity, for a mesic tropical savanna in northern Australia over 2 years. Our objectives are to (i) determine the utility of phenocams for identifying change in overstory and understory vegetation greenness, (ii) quantify the relationship between savanna overstory and understory phenology and productivity on seasonal and annual timescales, (iii) test if phenocam indices can be used as a proxy for improvement of a LUE model that is widely used to estimate GPP, and (iv) test the applicability of MODIS EVI for improving estimates of ecosystem-scale GPP. To do this we utilise one of the first phenocam datasets obtained in Australian ecosystems along with MODIS EVI and couple them with previously 
collected ecosystem, overstory and understory eddy covariance data (Moore et al., 2016a) to tease apart the tree and grass phenology-productivity relationship in Australian savanna.

\section{Methods}

\subsection{Site description}

This study was conducted at the Howard Springs OzFlux (www.ozflux.org.au/) and Fluxnet (AU-How) site (Beringer et al., 2016a) near Darwin in the Northern Territory, Australia. A record of carbon, water and energy flux, as well as meteorological and soil measurements, was first established at Howard Springs in 1997 (Eamus et al., 2001). As such, many detailed site descriptions exist (Beringer et al., 2007; Hutley et al., 2013; Beringer et al., 2015; Moore et al., 2016a). In brief, annual rainfall at Howard Springs is $1732 \mathrm{~mm}( \pm 44 \mathrm{SE}) \mathrm{mm}$ (Australian Bureau of Meteorology (BoM), station ID: 014015, www.bom.gov.au), of which 90$95 \%$ falls within the wet season months of October to April. As such, we defined the wet season as a 6-month period from 15 October to 15 April and the dry season as 16 April to 14 October, based on the work of Cook and Heerdegen (2001). Mean daily maximum air temperature varies annually between 30.6 to $33.3^{\circ} \mathrm{C}$ and mean daily minimum air temperature ranges from 19.3 to $25.3^{\circ} \mathrm{C}$ (Australian $\mathrm{Bu}$ reau of Meteorology, www.bom.gov.au/). Howard Springs is a mesic savanna as it receives $>1200 \mathrm{~mm}$ rainfall annually (Hutley et al., 2011) and is classified as "open forest savanna" based on its canopy cover fraction (50-60\%) after Specht (1972). Soils are mostly red Kandosols (Isbell, 1996) that are sandy-loamy, well weathered and nutrient poor.

Vegetation consists of a $\mathrm{C}_{3}$ woody overstory dominated by evergreen Eucalyptus miniata (Darwin woollybutt) and E. tetrodonta (Darwin stringybark). A smaller portion of the woody overstory is made up of semi-, brevi- and fully deciduous species such as Erythrophleum chlorostachys (Ironwood) and Terminalia ferdinandiana (Kakadu plum) (Williams et al., 1997; Hutley et al., 2011). Mean canopy height is $18 \mathrm{~m}$ (Hutley et al., 2011). The understory is dominated by the annual $\mathrm{C}_{4}$ grass Sorghum intrans (spear grass) and perennial $\mathrm{C}_{4}$ grasses Heteropogon triticeous and S. plumosum. Sharing the understory with the grasses are saplings (juveniles) of overstory species, the shrub Buchanania obovata and the cycad Cycas armstrongii. Due to the frequent occurrence of fire in Australian savanna (Beringer et al., 2015), control burning was performed at the beginning of each dry season to protect the monitoring equipment at the site.

\subsection{Productivity measurements}

To estimate productivity from the savanna ecosystem and partition it into tree (overstory) and grass (understory)
GPP, we used the eddy covariance technique (Baldocchi et al., 2001) as detailed for Howard Springs by Moore et al. (2016a). Two eddy covariance towers were in operation at Howard Springs to measure the fluxes of carbon, water and energy from both the understory (within tree canopy tower at $5 \mathrm{~m}$ ) and the ecosystem (above tree canopy tower at $23 \mathrm{~m}$ ) from 12 December 2012 to 14 October 2014. Overstory fluxes are simply the difference between ecosystem and understory fluxes, which represent the above ground tree fluxes. Instrumentation, validation of the understory tower, data quality assurance and quality control (QA/QC) and flux partitioning information is also provided in Moore et al. (2016a), so a summary is provided here.

Core eddy covariance instruments on each tower consisted of a 3-D sonic anemometer (CSAT3, Campbell Scientific, Logan UT) and an infrared gas analyser (LI-7500, LI-COR Biosciences, Lincoln, NE). These instruments sampled at a rate of $10 \mathrm{~Hz}$ and provided $30 \mathrm{~min}$ flux averages. Soil heat flux (HFT3, Campbell Scientific, Logan, UT) and net-/short/long-wave radiation components were also recorded on the ecosystem tower (CNR4, Kipp and Zonen, Delft, NL). The raw $30 \mathrm{~min}$ data were quality assured and controlled to level 3 standard using the OzFluxQC (v2.9.4) python scripts. Energy balance closure analysis of the ecosystem tower, based on daily data (Silva et al., 2011), gave a slope of 0.89 and an $r^{2}$ of 0.92 . The understory tower primarily recorded vertical transfer during turbulent conditions, which was validated via co-spectral analysis (Moore et al., 2016a) that followed idealised curves for vegetated canopies (Kaimal and Finnigan, 1994). Level 3 data were then gap filled and used to partition net ecosystem exchange (NEE) into respiration and GPP using the Dynamic INtegrated Gap filling and partitioning for OzFlux (DINGO; Beringer et al., 2016b) package. This package applied a $u^{*}$ filter, then, assuming all night-time NEE was respiration, an artificial neural network approach was used to fit NEE temperature response curves using soil temperature, air temperature and MODIS-derived EVI (daily interpolated; see Sect. 2.7) as the main model drivers. This was extrapolated to the daytime and GPP was calculated as the difference between NEE and respiration (Beringer et al., 2016b).

\subsection{Phenology and LUE measurements}

Alongside tower estimates of tree and grass productivity (12 December 2012 to 14 October 2014), we recorded incident, reflected and absorbed PAR and vegetation cover change. While the understory is largely homogenous in species distribution at the flux tower footprint scale (i.e. $>50 \mathrm{~m}$ ), variation does exist at the smaller scale (i.e. $<5 \mathrm{~m}$ ) due to its vegetation composition. To obtain a rigorous time series, spatial replicate measurements of vegetation cover change and PAR variability were recorded at five locations (on five tall mini towers) within a $50 \mathrm{~m}$ pentagon shape of the main ecosystem flux tower (Fig. 1). 

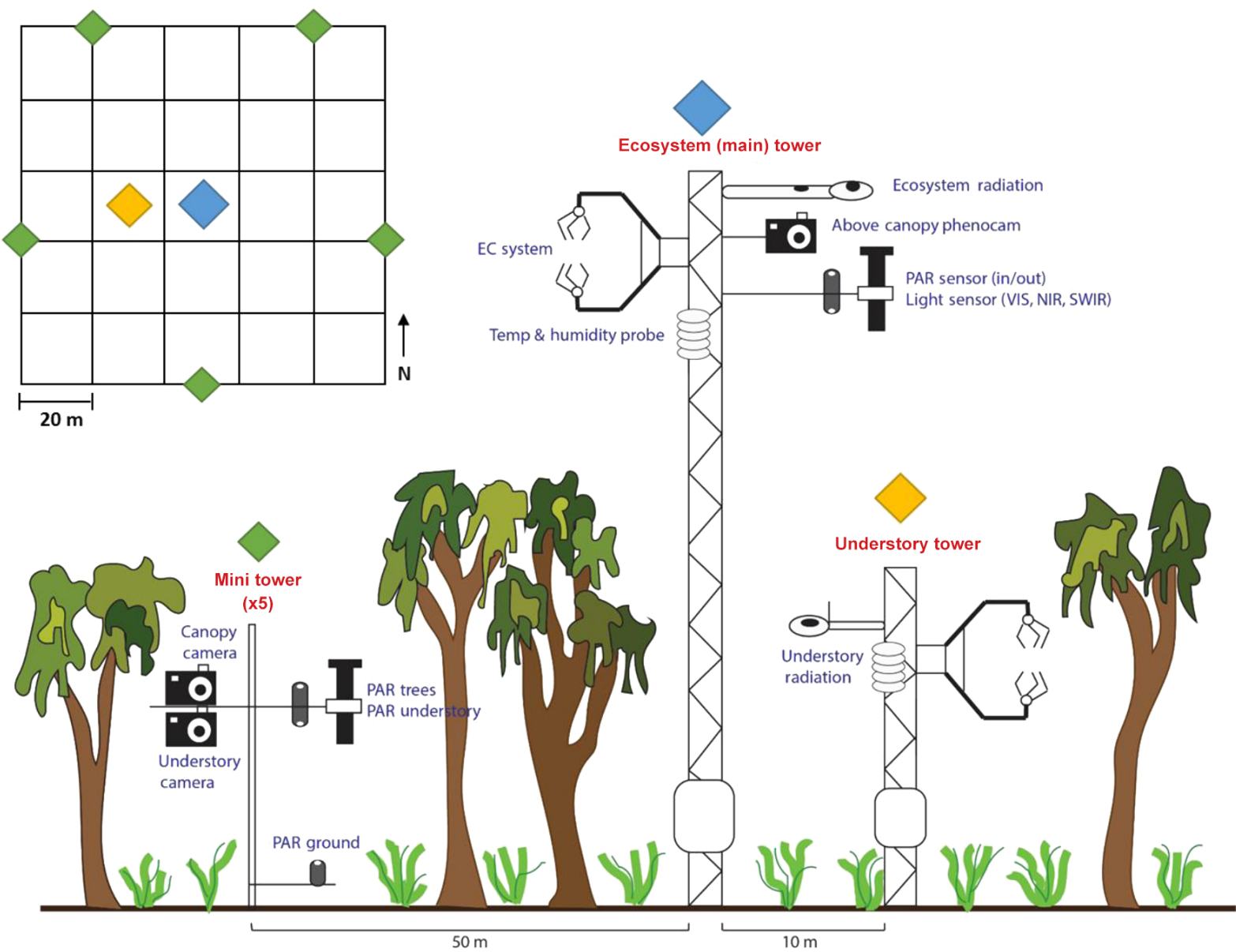

Figure 1. Diagram showing the core instrumentation supported by each flux tower and mini tower at the Howard Springs OzFlux site, as well as the layout of the monitoring plot.

PAR components for the overstory and understory were measured from PAR sensors on each of the mini towers (SQ series, Apogee, Logan, UT). A data logger (CR800, Campbell Scientific, Logan UT) and multiplexor (AM25T, Campbell Scientific, Logan, UT) were used to collect and store data and to operate the phenocams. The systems were powered using a $20 \mathrm{~W}$ solar panel, $12 \mathrm{~V}$ regulator and $12 \mathrm{~V}$ gel cell battery. To provide a complete accounting of savanna PAR, two additional sensors (LI-190 Quantum Sensor, LI-COR Biosciences, Lincoln, NE) were installed on the $23 \mathrm{~m}$ flux tower for collection of incoming PAR and outgoing PAR reflected from the savanna ecosystem.

Changes in savanna overstory and understory vegetation greenness were assessed using consumer-grade point-andshoot cameras (Canon Powershot A810). Each mini tower supported two cameras, one collecting upward-facing images of the tree canopy (field of view (FOV) of $\sim 8 \times 5 \mathrm{~m}$ ) and one collecting downward-facing images of the understory (FOV $\sim 4 \times 2 \mathrm{~m}, 10$ cameras total). The cameras' settings included automatic exposure in aperture priority mode, with a low f/stop (focal point) value of 2.8 to ensure the entire im- age was used to respond to ambient light levels (Richardson et al., 2007; Ryu et al., 2012; Sonnentag et al., 2012). Automatic white balance was also used as we did not have a grey reference panel to correct for white balance manually. Images were stored in a compressed JPEG file format and each camera was housed in a makeshift waterproof case (Fig. 2a, d).

Following the concept of Ryu et al. (2012), power was delivered to the cameras through wires soldered to the battery terminals and a brief pulse delivered to wires soldered to the camera "on-button" allowed them to turn on when prompted. The Canon Hack Development Kit (http://chdk. wikia.com/wiki/CHDK) was used to automate image capture when the camera was turned on, which was administered via a uBASIC script saved on the memory card. Each mini tower logger was programmed to operate the cameras twice daily, once at 11:30 ACST ( $\sim$ MODIS Terra overpass) and once at 13:00 ACST ( $\sim$ solar noon). Each camera was installed at an angle of $57.5^{\circ}$ from zenith to minimise the effects of leaf inclination angle when calculating LAI (Weiss et al., 2004; Baret et al., 2010). 
(a)
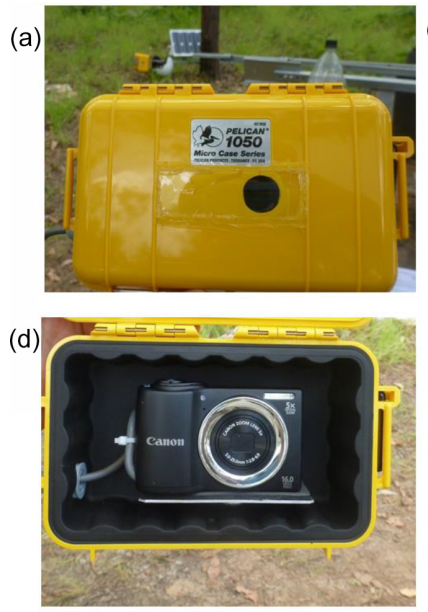

(b)

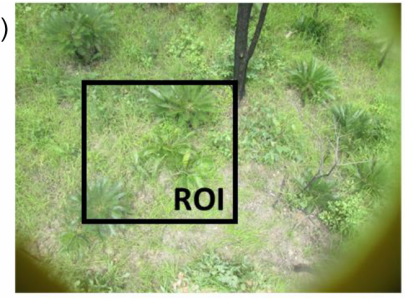

(e)

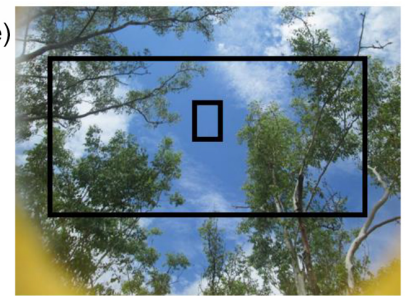

(c)

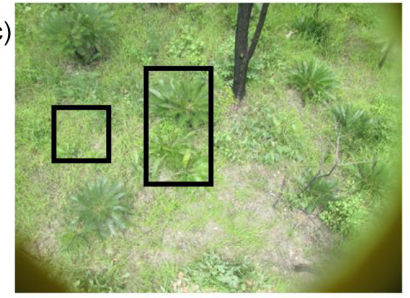

(f)

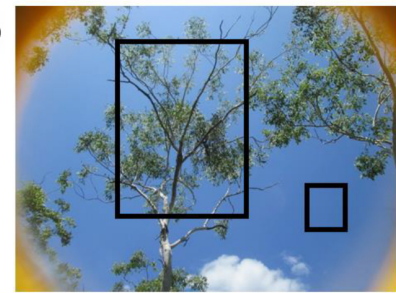

Figure 2. Camera setup (a, d) and examples of understory $(\mathbf{b}, \mathbf{c})$ and overstory $(\mathbf{e}, \mathbf{f})$ regions of interest (ROI, black box) used from phenocam images collected at the Howard Springs OzFlux site.

\subsection{Phenocam image processing}

Phenocam images were visually checked for FOV shifts and major obstructions (i.e. water in image) as a first step in the image QA/QC process. Images with obstructions were removed, which accounted for between 3 and $13 \%$ of images for each camera. However, 3 out of 10 cameras were completely omitted from analysis due to severe FOV shifts or where an individual camera had greater than $50 \%$ of images lost, leaving a total of four cameras for understory analysis (5031 images total) and three for the overstory (4255 images total). All remaining cameras $(n=7)$ experienced slight FOV shifts as a result of manual data download. However, a Student $t$ test of 686 analysed images, for a camera with a large visible FOV shift, revealed no significant effect on the extracted results $\left(t_{686}=0.13, p=0.90\right)$. The time series from each camera were then gap filled using the best regression relationship against another camera, most of which had an $r^{2}>0.8$.

Images were analysed in date/time succession using a region of interest (ROI) that encompassed as much of the vegetation as feasible. As a result, the ROI varied depending on the vegetation available in the overstory FOV and was the same for all understory cameras, except for a separate analysis of grass and woody green vegetation (Fig. 2). In addition, we analysed a separate sky-only ROI for each overstory camera and used the sky data to filter out sky-pixel information from the calculation of each index (Fig. 2 and Supplement). Each camera collected 8 bit depth red-green-blue (RGB) colour channel information, stored as digital numbers $(\mathrm{DN})$, at a resolution of $4608 \times 3456$ pixels. These DNs provide a measure of colour intensity based on irradiance, so they can vary when scene illumination changes (Ide and Oguma, 2010; Sonnentag et al., 2012). To reduce the effects of scene illumination, the DNs are typically used to calculate the green chromatic coordinate (GCC), a normalised ratio of the green channel to all channels, as Eq. (1) (Gillespie et al., 1987; Woebbecke et al., 1995):

$\mathrm{GCC}=\mathrm{G}_{\mathrm{DN}} /\left(\mathrm{R}_{\mathrm{DN}}+\mathrm{G}_{\mathrm{DN}}+\mathrm{B}_{\mathrm{DN}}\right)$,

where $\mathrm{DN}$ is the digital number that corresponds with the green $(\mathrm{G})$, red (R) and blue (B) channels. The red (RCC) and blue (BCC) chromatic coordinates were calculated in the same way as GCC. Chromatic coordinate values were calculated for each pixel within the ROI and then averaged to give an overall GCC, RCC and BCC value for each image. We also calculated the excess green (ExG), red (ExR) and blue (ExB) indices to compare which colour index performed best at capturing savanna phenological change. The excess index is an enhancement of the respective colour channel information against the other channels and is calculated as Eq. (2) (Woebbecke et al., 1995):

$E x G=2 G_{D N}-\left(R_{D N}+B_{D N}\right)$.

\subsection{Radiation data processing}

The amount of light absorbed by vegetation over time is directly correlated with productivity (Monteith, 1972). Using mini tower PAR data, we calculated fPAR for the overstory (OS) Eq. (3), understory (US) Eq. (4) and ecosystem (ECO) Eq. (5) as

$$
\begin{aligned}
& f \mathrm{PAR}_{\mathrm{OS}}=\left(\mathrm{PAR}_{\mathrm{AED}}-\mathrm{PAR}_{\mathrm{AEU}}-\mathrm{PAR}_{\mathrm{AGD}}\right) / \mathrm{PAR}_{\mathrm{AED}}, \\
& f \mathrm{PAR}_{\mathrm{US}}=\left(\mathrm{PAR}_{\mathrm{AGD}}-\mathrm{PAR}_{\mathrm{AGU}}-\mathrm{PAR}_{\mathrm{BGD}}\right) / \mathrm{PAR}_{\mathrm{AGD}}, \\
& f \mathrm{PAR}_{\mathrm{ECO}}=\left(\mathrm{PAR}_{\mathrm{AED}}-\mathrm{PAR}_{\mathrm{AEU}}-\mathrm{PAR}_{\mathrm{BGD}}\right) / \mathrm{PAR}_{\mathrm{AED}},
\end{aligned}
$$

where AED and AEU are the above ecosystem downwelling and upwelling PAR, AGD and AGU are the above grass 
(a)
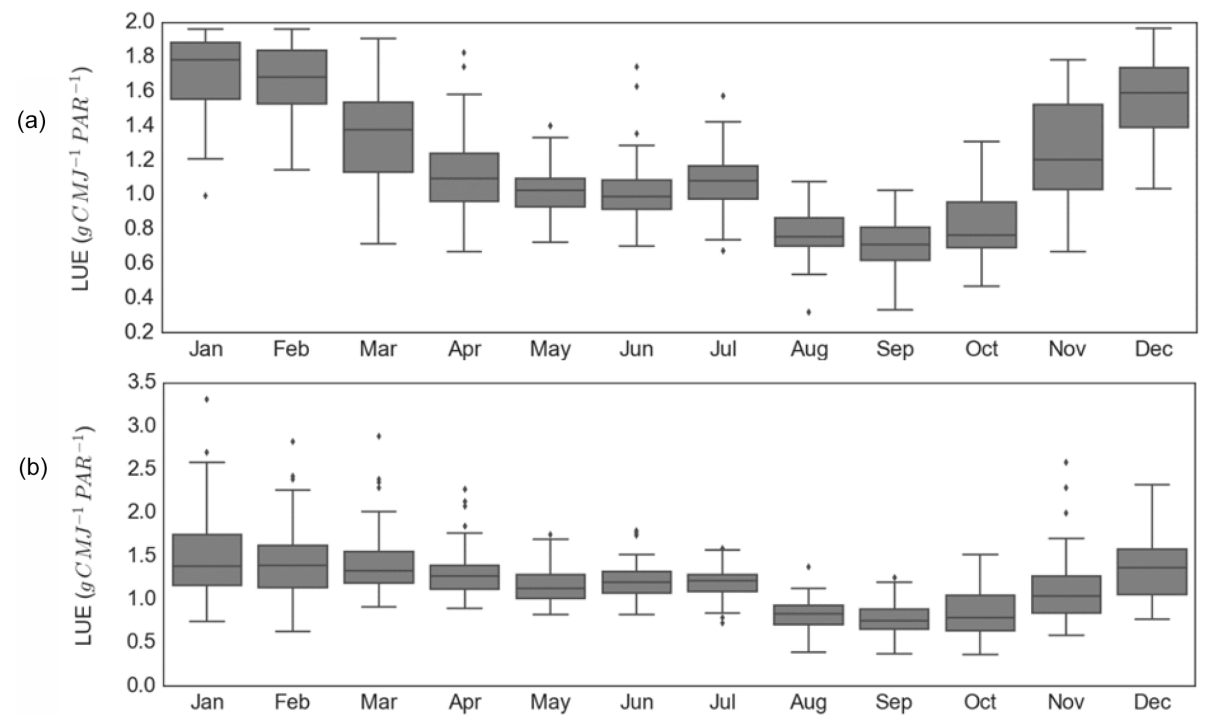

(c)

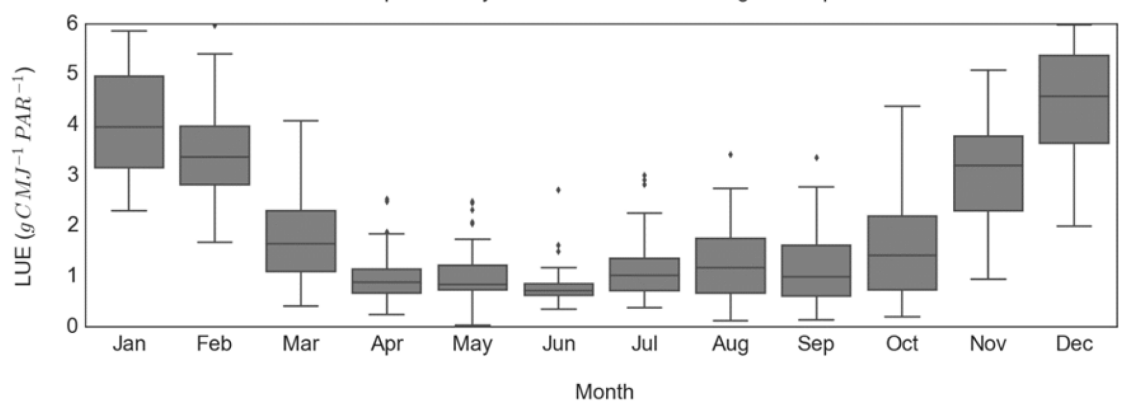

Figure 3. Monthly mean light use efficiency (LUE) \pm SE (boxes) with $95 \%$ confidence (whiskers) for the Howard Springs OzFlux site ecosystem (a), overstory (b) and understory (c) from December 2012 to October 2014. Individual dots represent outlier values for each respective month.

downwelling and upwelling PAR and BGD is the below grass downwelling PAR. Using fPAR, APAR was calculated for overstory, understory and ecosystem by multiplying the respective fPAR with available incoming PAR (note: this was PAR $_{\text {AGD }}$ for the understory).

\subsection{Leaf area index and biomass measurements}

Variability of vegetation LAI and biomass over time is a direct result of phenology and productivity. We collected overstory LAI on each site visit (six total) using digital hemispheric photography from a Canon digital single lens reflex (DSLR) camera (Rebel T1i) with a $185^{\circ}$ super fisheye FOV $(f / 5.6)$ lens. The images were taken around a onehectare plot ( $n=36$, Fig. 1$)$ and analysed using WinScanopy (v2014a). A clumping coefficient was calculated to account for foliage clumping in the LAI estimate, which was verified using a Tracing Radiation and Architecture of Canopies (TRAC) instrument. These techniques agreed within 10$15 \%$ of each other ( 0.82 to 0.94 in the wet season, 0.61 to 0.67 in the dry season). Understory biomass below $2 \mathrm{~m}$ in height was collected from 20 replicate $1 \times 1 \mathrm{~m}$ quadrats along a N-S and E-W $100 \mathrm{~m}$ transect (10 samples each, every $5 \mathrm{~m}$ ) over a full growing season (December-April, 4 total). Samples were separated into grass and other green biomass, weighed, then oven dried at $80^{\circ} \mathrm{C}$ for 3 days to obtain dry weight. Following Chen et al. (2003), we converted the dry weight biomass into carbon content assuming it to be $43 \%$ of grass biomass and $49 \%$ of other green biomass.

\subsection{LUE models and incorporation of phenology}

An alternative to estimating GPP from flux towers is to use a LUE model, where GPP is approximated by relating plant productivity to the amount of light they absorb over a growing season (Monteith, 1972). The MODIS GPP product (MOD17 A2.055) is calculated using a LUE model (Eq. 6; Running and Zhao, 2015), which we use in this study, as it has been validated for Australian savannas (Kanniah et al., 2009):

$\mathrm{GPP}=\mathrm{APAR} \times \mathrm{LUE}_{\mathrm{p}} \times T_{\mathrm{MIN}} \mathrm{scalar} \times \mathrm{VPD}$ scalar,

where GPP is in $\mathrm{g} \mathrm{Cm}^{-2} \mathrm{~d}^{-1}$, APAR is in $\mathrm{MJd}^{-1}$ and LUE $_{\max }$ is the general maximum light use efficiency during the wet season in $\mathrm{g} \mathrm{CMJ}^{-1} \mathrm{PAR}^{-1}$. Because $\mathrm{C}_{3}$ (trees) and $\mathrm{C}_{4}$ (grasses) plants have different 
maximum LUE rates (Zhu et al., 2008), we calculated overstory and understory $\mathrm{LUE}_{\max }$ separately following a similar approach to Kanniah et al. (2009) and Coops et al. (2007), where LUE is firstly calculated as GPP / APAR and is then binned by month to obtain monthly LUE. We chose to use the months of December-March (inclusive) to provide an estimate of $\mathrm{LUE}_{\max }$ for the overstory and understory, as these months $(n=8$, across 2 years) have the least environmental constraints to productivity and should be close to the maximum. This gave us a $\mathrm{LUE}_{\max }$ value of $1.58 \pm 0.06 \mathrm{~g} \mathrm{CMJ}^{-1} \mathrm{PAR}^{-1}$ for the ecosystem, $1.43 \pm 0.06 \mathrm{~g} \mathrm{C} \mathrm{MJ}^{-1} \mathrm{PAR}^{-1}$ for the overstory and $3.45 \pm 0.41 \mathrm{~g} \mathrm{C} \mathrm{MJ}^{-1} \mathrm{PAR}^{-1}$ for the understory (Fig. 3). In the LUE model the LUE $_{\max }$ values are then down regulated on a daily basis using the VPDscalar Eq. (7) and $T_{\mathrm{MIN}}$ scalar (values between 0 and 1) Eq. (8) (Running and Zhao, 2015):

VPD scalar $=\left(\mathrm{VPD}_{\max }-\mathrm{VPD}_{\mathrm{d}}\right) /\left(\mathrm{VPD}_{\max }-\mathrm{VPD}_{\min }\right)$,

$T_{\mathrm{MIN}} \mathrm{scalar}=\left(T_{\mathrm{MIN}}-T_{\mathrm{MIN} \min }\right) /\left(T_{\mathrm{MIN} \max }-T_{\mathrm{MIN} \min }\right)$,

where $T_{\mathrm{MIN}}$ is the minimum daily temperature for a given day, $T_{\mathrm{MIN} \text { max }}$ is the minimum daily temperature when LUE is at maximum and $T_{\mathrm{MIN} \text { min }}$ is the minimum daily temperature when LUE is 0 , all of which are output in ${ }^{\circ} \mathrm{C}$. Likewise, $V P D_{d}$ is the mean daytime VPD, VPD max is the maximum VPD when LUE is 0 and $V_{P D}$ in is the minimum VPD when LUE is at maximum, all output in Pa. These scalar values range between 0 and 1 . The MOD17 GPP algorithm uses values of $-8{ }^{\circ} \mathrm{C}$ for $T_{\mathrm{MIN} \text { min }}, 11.39^{\circ} \mathrm{C}$ for $T_{\mathrm{MIN} \text { max }}, 650 \mathrm{~Pa}$ for $\mathrm{VPD}_{\min }$ and $3500 \mathrm{~Pa}$ for $\mathrm{VPD}_{\max }$ for savannas (Running and Zhao, 2015). These values were validated for Howard Springs by Kanniah et al. (2009), so we used them in our study.

The use of a soil moisture term, evaporative fraction (EF), has been argued to represent plant available moisture more reliably than VPD (Gentine et al., 2007; Yuan et al., 2007; Kanniah et al., 2009). This term is simply a fractional estimate of latent heat (LE) divided by the sum of sensible heat $(H)$ and $\mathrm{LE}$ (i.e. $\mathrm{LE} /(\mathrm{LE}+H))$. We also used $\mathrm{EF}$ in this study to test if it improved the estimation of overstory, understory and ecosystem GPP. For the overstory and ecosystem, we calculated EF using the ecosystem flux tower, whereas for the understory we calculated EF using the understory flux tower.

Another technique we tested for improving GPP estimates from the LUE model was to input phenocam greenness indices, as they have been found to correlate with ecosystem productivity in northern hemispheric forests and grasslands (Richardson et al., 2009b; Migliavacca et al., 2011; Toomey et al., 2015). We hypothesised that inclusion of GCC in the LUE model would improve the model's ability to predict savanna overstory and understory GPP, particularly given the strong phenology cycles displayed in savannas. As GCC is

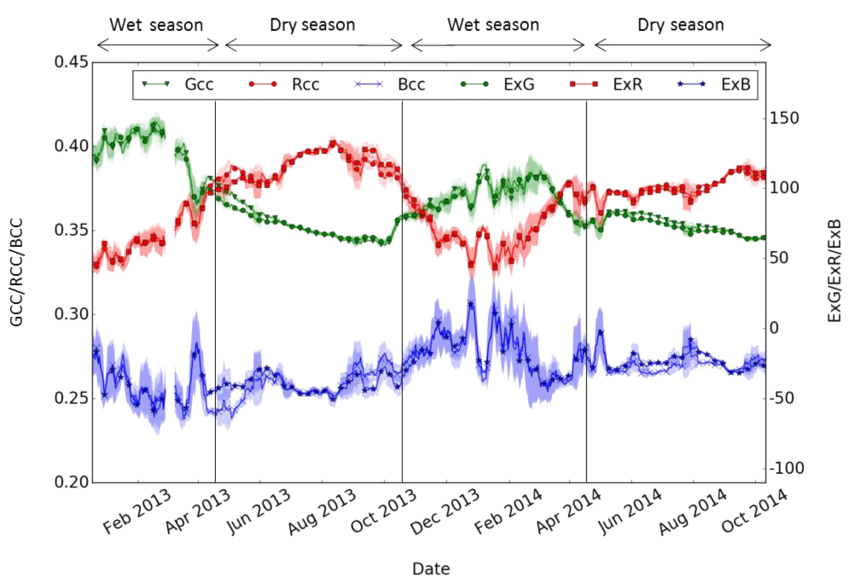

Figure 4. Daily green, red and blue chromatic coordinates (GCCRCC-BCC) and excess indices (ExG-ExR-ExB) for the Howard Springs OzFlux site understory from December 2012 to October 2014. Daily data are shown with an 8-day centred running mean (marked every 8 days for visualisation) applied. The standard error of the mean is given by the shading.

a fractional measure, like that of fPAR, we substituted GCC as a proxy for fPAR using the coefficients of a regression to normalise it, a similar approach to that used by Migliavacca et al. (2011). As a result, Eq. (6) was transformed to include PAR $\times(\mathrm{mGCC}+c)$ in place of APAR, where $m$ and $c$ are the linear regression coefficients.

We repeated the above technique using MODIS EVI (Huete et al., 2002) to test if satellite indices could be used to improve estimates of ecosystem-scale GPP. We chose the EVI product (MOD13Q1.005) as it has been shown to function well for identifying broad-scale phenology in Australian savannas (Ma et al., 2013, 2014). A $3 \times 3$ pixel cut-out of EVI data surrounding the Howard Springs site, at 16-day and $250 \mathrm{~m}$ resolution, was processed in DINGO, accepting the quality flags 00 (highest overall quality) and 01 (good quality) only. The 16-day data were then interpolated and smoothed, using a Savitzky-Golay technique (Savitzky and Golay, 1964) in DINGO, to create a daily time series of EVI (Beringer et al., 2016b). Daily EVI were regressed against site-based daily ecosystem fPAR and the regression was used along with incoming PAR to replace APAR in Eq. (6).

Finally, to test the performance of each model against tower GPP estimates, we used a Pearson correlation to provide a closeness of fit estimate (Corr) and test whether the relationship was statistically significant $(p<0.05)$. We also calculated the root mean square error (RMSE) to provide a measure of the difference between the two datasets (tower and model) and the relative predictive error (RPE) to represent the percentage difference and degree of overestimation $(+)$ or underestimation $(-)$ of the model. 


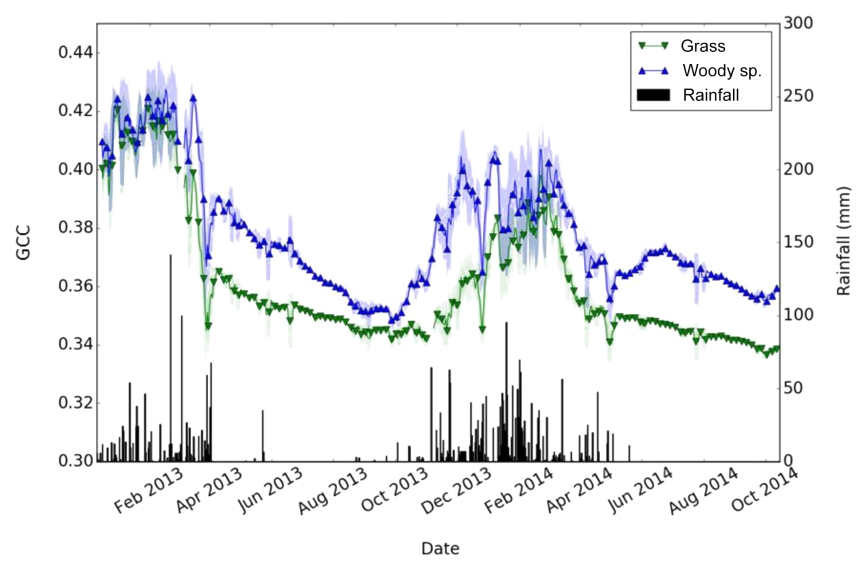

Figure 5. Daily rainfall $(\mathrm{mm})$ and green chromatic coordinate (GCC) time series for grass and other woody green species (woody sp.) found in the savanna understory at the Howard Springs OzFlux site from December 2012 to October 2014. The GCC daily data are shown with an 8 -day centred running mean (marked every 8 days for visualisation) applied. The standard error of the mean is given by the shading. The GCC time series represent the change in relative greenness of grass and woody species, not the absolute sum of grass versus woody species biomass in the understory.

\section{Results and discussion}

\subsection{Phenological insights from phenocams}

The phenocam indexes revealed expected patterns from overstory and understory vegetation over time, showing the cameras functioned well as phenology monitors of vegetation at the ecosystem and species level (Figs. 4, 5, 6). Not surprisingly, both GCC and ExG were highest in the understory during the wet season and lowest by the late dry season (i.e. September; Fig. 4). The RCC and ExR indices showed an inverse relationship to GCC and ExG, which is symptomatic of increased red pigmentation from senescing leaves and chlorophyll loss (Hoch et al., 2001; Lee et al., 2003; Wingate et al., 2015). This relationship is shown by the redgreen index crossover in the understory that coincides with grass senescence and signals the end of the wet season (i.e. March/April; see Fig. 4), along with an increase in the red kandosol soil background showing through with the loss of understory biomass. At the beginning of the wet season (October to November), the red-green crossover takes longer to occur than at the end of the wet season (Fig. 4). Several rainfall events in November (Figs. 4, 5 for rainfall) are required to reach the crossover, which is indicative of the vegetation response to the onset of the rainy season (i.e. grasses need time to germinate). Peak GCC and ExG are not reached until February (Fig. 4), the period of highest productivity for total understory biomass (Table 1).

The understory is a mix of annual (S. intrans) and perennial (S. plumosum and $H$. triticeous) grasses, overstory ( $E$. tetrodonta and E. miniata) and mid-story (E. chlorosyachys,
Table 1. Understory biomass harvest information for Howard Springs savanna collected across the wet seasons from 2012 to 2014.

\begin{tabular}{lrrrr}
\hline Period & $\begin{array}{r}\text { Grass } \\
\text { biomass } \\
\left(\mathrm{t} \mathrm{ha}^{-1}\right)\end{array}$ & $\begin{array}{r}\text { Other } \\
\text { biomass } \\
\left(\mathrm{tha}^{-1}\right)\end{array}$ & $\begin{array}{r}\text { Grass } \\
\text { biomass } \\
(\%)\end{array}$ & $\begin{array}{r}\text { Other } \\
\text { biomass } \\
(\%)\end{array}$ \\
\hline Start - Dec & 0.46 & 0.96 & 33 & 67 \\
Mid - Feb & 1.34 & 1.77 & 43 & 57 \\
Peak - Mar & 1.55 & 1.09 & 59 & 41 \\
End - Apr & 1.31 & 0.38 & 77 & 23 \\
\hline
\end{tabular}

T. ferdinandiana and B. obovata) saplings, and cycads ( $C$. armstrongii) that all have differing phenologies (Bowman and Prior, 2005). The dynamic nature of these phenological guilds is reflected in the temporal patterns of GCC and ExG between grasses and the non-grass woody elements (herein "woody green"; Fig. 5). While grasses are the most abundant understory species in terms of biomass (Table 1) and LAI at Howard Springs (Hutley et al., 2000), they are only active during the wet season (Andrew and Mott, 1983; Scott et al., 2010). During the early wet (October/November) and dry (April/May) seasons, the woody green species take advantage of the lack of grass to gain biomass (Werner and Franklin, 2010; Werner and Prior, 2013).

Annual grasses typically germinate after the first $15 \mathrm{~mm}$ or more of rainfall, with further rainfall events required to drive leaf growth (Andrew and Mott, 1983; Cook et al., 2002). Pre-monsoonal rainfall is highly variable in its timing and amount; therefore this phenological strategy may minimise grass mortality if dry periods proceed an initial early wet season rainfall event (Moore et al., 2016a). In Fig. 5, this delay in grass greening is evident, with rapid increases in GCC occurring 1 month after the first rainfall event (Fig. 5; OctoberDecember 2013). Phenocam data can therefore tease apart composite greening signals to better understand phenological dynamics and fluxes in these ecosystems (Figs. 5, 7). Understory biomass data also support the GCC results, revealing that as the wet season progressed, the grasses increased in dominance to account for $77 \%$ of understory biomass by the end of the wet season (Table 1). While the grasses are the primary driver of understory biomass and productivity, the woody green species also make important contributions throughout the year and are likely the reason why understory GPP does not completely cease in the dry season (Moore et al., 2016a).

In contrast to the understory, overstory GCC and ExG did not fluctuate much when compared to the red and blue channel indices (Fig. 6a). This is mostly due to the high portion of blue sky and cloud within the ROIs for the overstory images (Fig. 2e, f), which vary depending on daily weather conditions. However, application of a sky threshold, calculated from a sky-only ROI, improved the seasonal pattern seen in overstory GCC (see Supplement) and contributed to remov- 


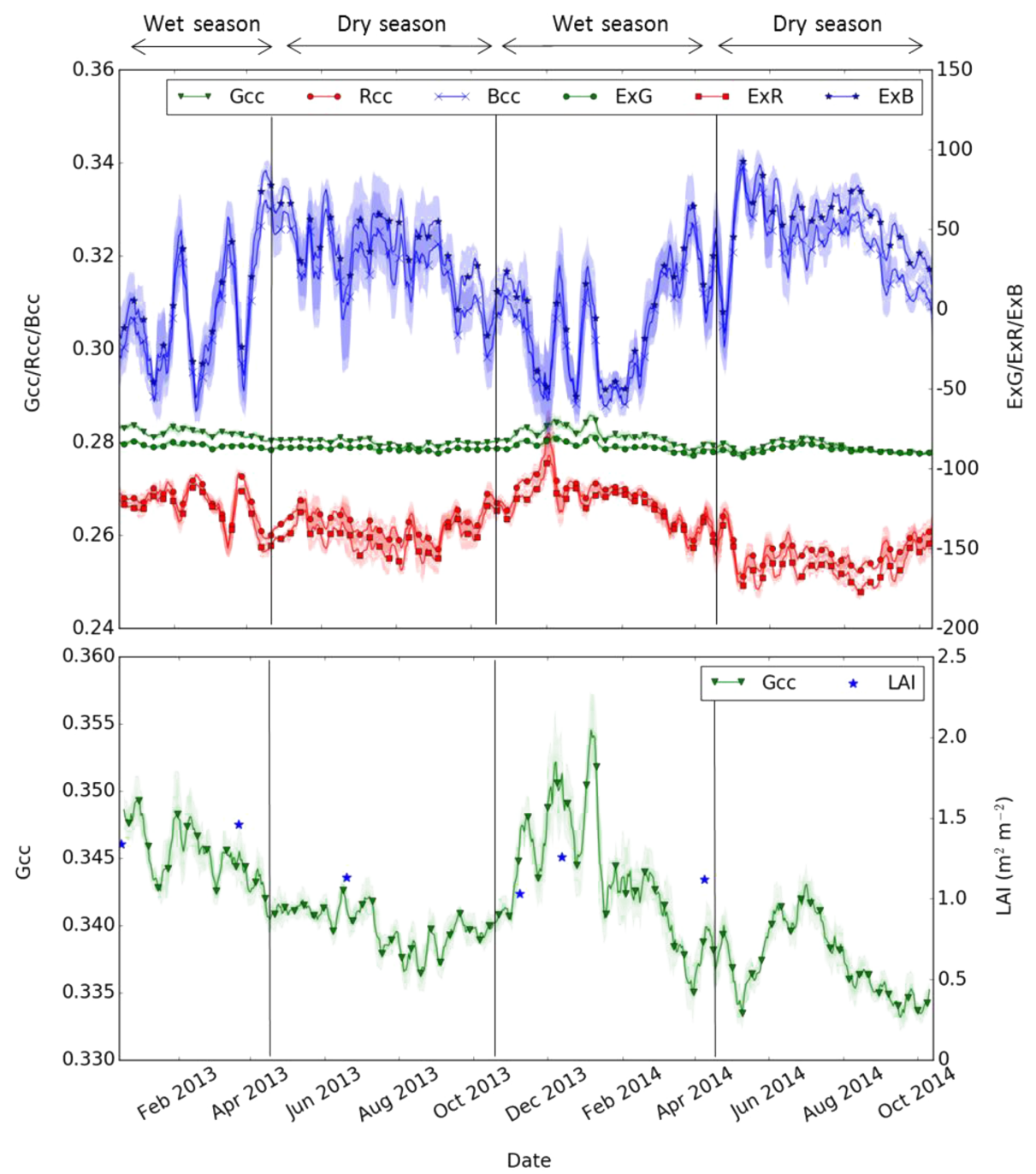

Figure 6. Daily green, red and blue chromatic coordinates (GCC-RCC-BCC) and excess indices (ExG-ExR-ExB) for the Howard Springs OzFlux site overstory (a), plus GCC and leaf area index (LAI) for the overstory (b) from December 2012 to October 2014. Daily data are shown with an 8-day centred running mean (marked every 8 days for visualisation) applied. The standard error of the mean is given by the shading.

ing the influence of sky pixels on the GCC calculation. These values also agreed with changes in overstory LAI (Fig. 6b). A larger ROI was necessary for the overstory analysis due to the daily movement of trees. While there is inherent uncertainty in both the phenocam imagery (i.e. FOV, scene illumination) and LAI (i.e. leaf projection and orientation, clumping, gaps; see Ryu et al., 2010) estimates in this study, the savanna overstory is known to experience seasonal fluctuations in LAI with the highest values in the wet season and lowest values in the late dry season (Williams et al., 1997; O'Grady et al., 2000). The same pattern is displayed in Fig. 6, giving us confidence that the phenocams were able to detect overstory cover change.

\subsection{Phenocam and MODIS phenology in relation to GPP}

The seasonality of GPP in these savannas has been found to differ between that of the overstory and understory, with understory GPP tied more closely to the duration of the wet season than that of the overstory (Moore et al., 2016a). The GCC and ExG time series appeared to capture the overstory and understory GPP estimates (Fig. 7), so we hypothesised that they could be useful for independently predicting overstory and understory GPP. Simple linear regressions of GCC against flux tower GPP quantified the relationship between the two variables, with understory GPP $\left(r^{2}=0.65\right)$ revealing a closer fit with GCC than overstory GPP $\left(r^{2}=0.23\right.$, Fig. 7). The ExG index did not perform so well compared with GCC 

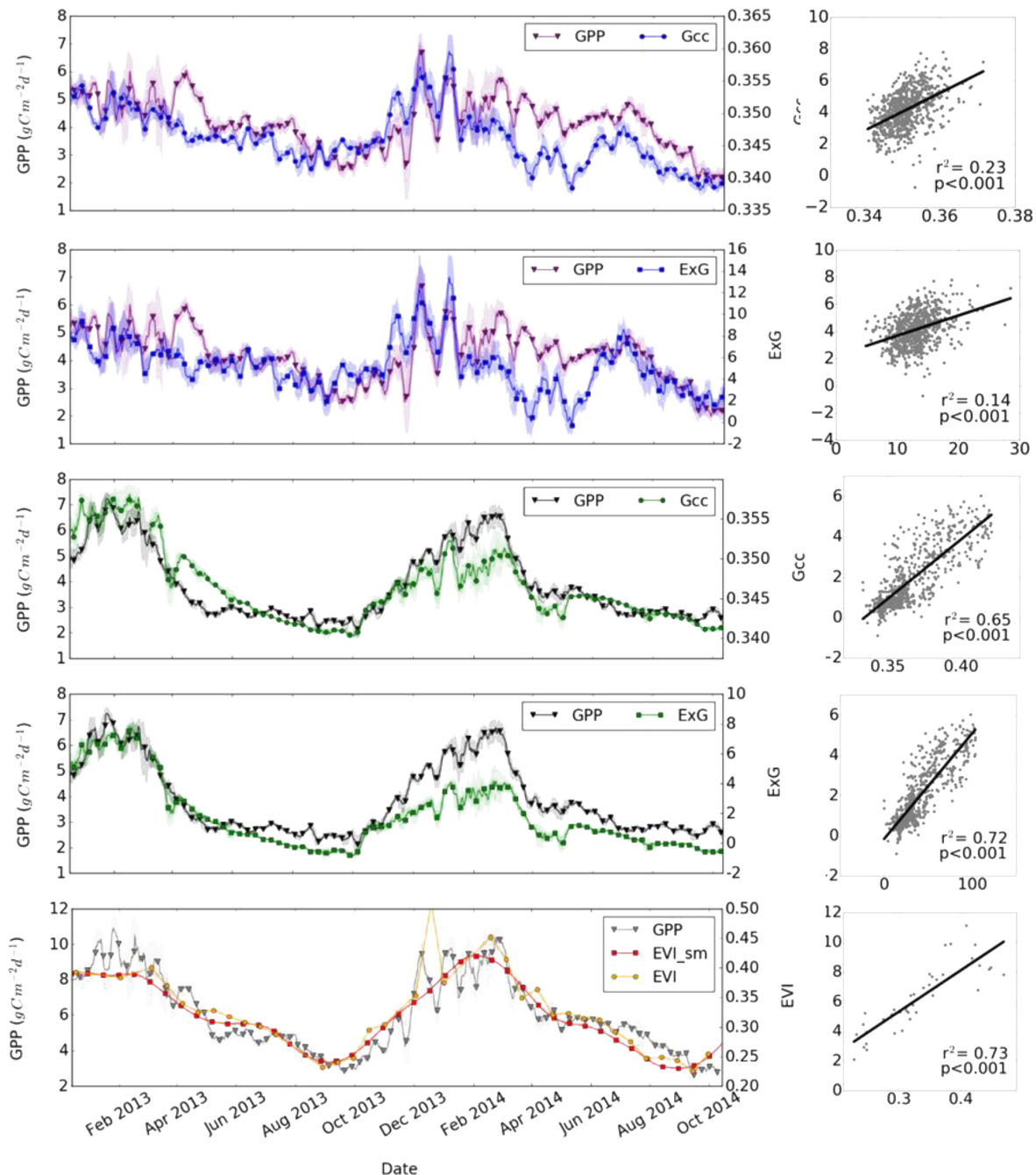

Figure 7. Overstory (a, b) and understory (c, d) flux tower GPP with green chromatic coordinate (GCC) and excess green (ExG) indices, as well as ecosystem flux tower GPP with MODIS enhanced vegetation index (EVI, e), from December 2012 to October 2014 at the Howard Springs OzFlux site. Daily data are shown with an 8-day running mean (marked every 8 days for visualisation) applied. The standard error of the mean is given by the shading. Included for each time series are the respective regression plots showing $r^{2}$ and $p$ values for GCCExG-EVI $(x)$ against flux tower GPP $(y)$. For MODIS EVI (e) the time series plot includes raw 16-day values (EVI) and a Savitzky-Golay smoothed daily EVI product (EVI_sm), with the regression plot showing the raw 16-day EVI and the corresponding GPP for that day.

for the overstory $\left(r^{2}=0.14\right)$ but improved the relationship slightly against GCC for the understory $\left(r^{2}=0.72\right.$, Fig. 7). ExG was originally developed for identifying green vegetation from images with a soil background (Woebbecke et al., 1995). This is a likely reason for why the relationship between ExG and GPP was slightly closer than that of GCC for the understory.

While the relationship between overstory greenness (ExG-GCC) and GPP is not as strong as that of the understory, the phenocams were still able to detect seasonality in greenness that followed GPP over time (Fig. 7). The trees have a deeper rooting structure than the grasses, allowing them to access a larger volume of soil moisture (Eamus et al., 2002; Kelley et al., 2007) and thus maintain constant over- story transpiration throughout the year (O'Grady et al., 1999; Hutley et al., 2000). While the tree canopy is largely evergreen, the LAI will drop up to 30-40\% in order to account for the dry season water deficit (O'Grady et al., 2000; Whitley et al., 2011), which is also apparent from both our overstory LAI and GCC results (Fig. 6). Tree productivity, in contrast to transpiration, is known to decrease into the dry season (Eamus et al., 1999), and most carbon uptake is directed toward maintenance respiration rather than growth (Chen et al., 2002; Prior et al., 2004; Cernusak et al., 2006). However, the occurrence of late wet season rainfall events may benefit the productive capacity of the trees by boosting soil moisture stores, thereby supporting higher rates of productivity for longer in the dry season (Moore et al., 2016a). This effect 

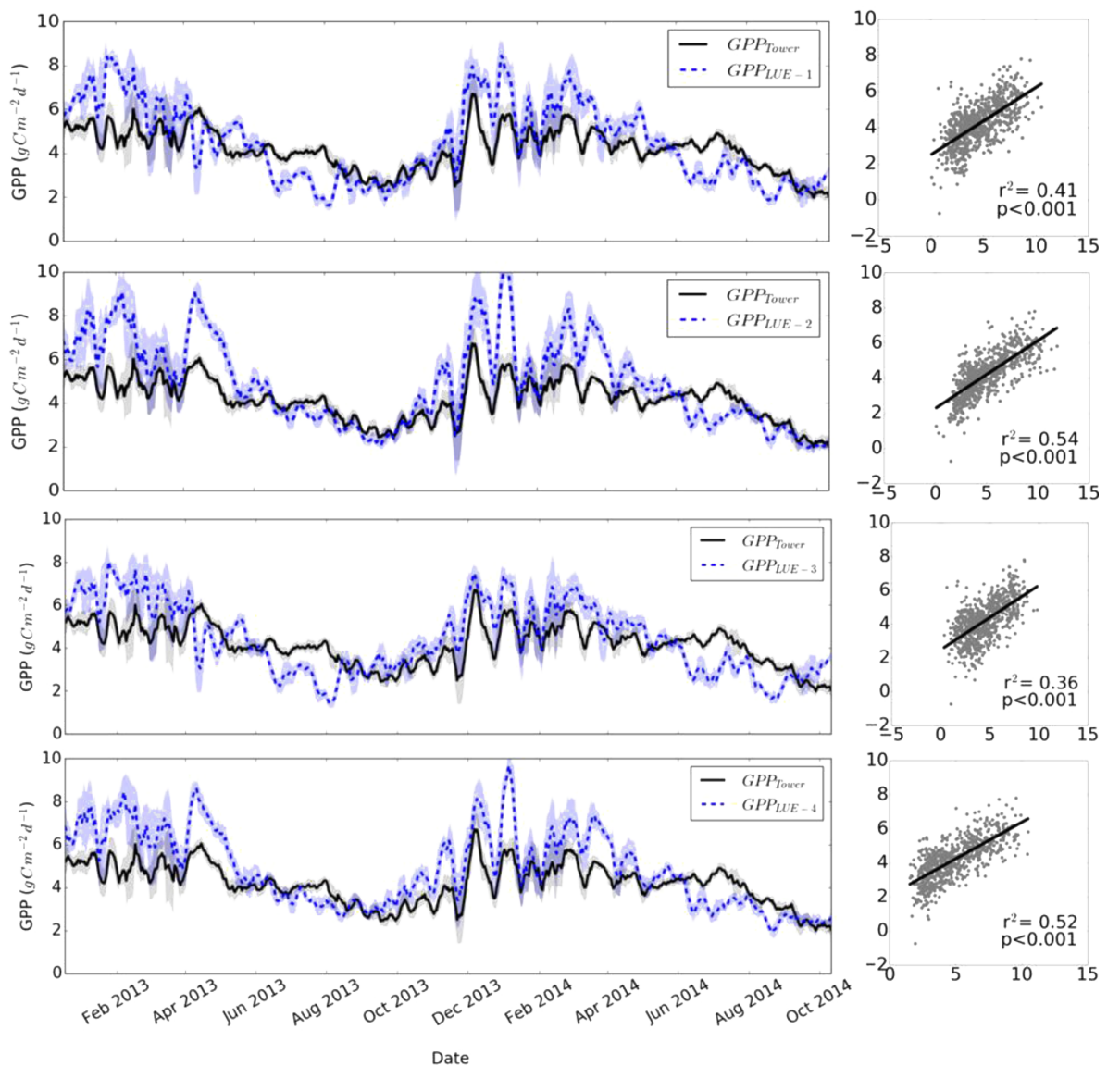

Figure 8. Overstory flux tower estimated GPP with model predicted GPP for the Howard Springs OzFlux site. Models shown are (a) light use efficiency (LUE-1), (b) LUE with evaporative fraction (LUE-2), (c) LUE with green chromatic coordinates (LUE-3) and (d) LUE with EF and GCC (LUE-4).

is apparent in our overstory GCC time series, where after late April to early May rainfall events (see Fig. 5 for daily rainfall) GCC spikes in June indicate a flushing of the foliage in the dry season (Fig. 6b).

At the ecosystem scale, the interaction of the overstory and understory with the wet and dry seasons drives variability in productivity. The MODIS greenness index, EVI, mostly captures this variability, albeit at coarser temporal resolution (Fig. 7e) when compared with the phenocams. While the broad-scale variability in savanna phenology change is captured by EVI, such as seasonality (Ma et al., 2013), it is not able to capture the finer-scale details that the site-based phenocams can. MODIS indices, such as EVI, do not currently have the ability to identify individual plant-scale phenology patterns (Brown et al., 2016; Moore et al., 2016b), which is another advantage of the phenocam (Fig. 5). The phenocam data also provide a useful means of validating the MODIS data in that both are able to track the seasonality of savanna GPP, which is driven by a complex interaction of both meteorology and phenology (Kanniah et al., 2011; Whitley et al., 2011; Ma et al., 2013, 2014).

\subsection{Integrating phenocam and MODIS phenology with a LUE model}

To use greenness phenology information for predicting GPP from the LUE model, an estimate of maximal LUE was calculated, which was higher for the understory $\left(3.45 \pm 0.41 \mathrm{~g} \mathrm{C} \mathrm{MJ}^{-1} \mathrm{PAR}^{-1}\right)$ compared to the overstory $\left(1.43 \pm 0.06 \mathrm{~g} \mathrm{C} \mathrm{MJ}^{-1} \mathrm{PAR}^{-1}\right.$; Fig. 3$)$. The higher $\mathrm{LUE}_{\max }$ for the understory is largely due to the dominance of $\mathrm{C}_{4}$ grasses in the understory (Table 1 ), as their $\mathrm{C}_{4}$ photosynthetic pathway is more energy efficient (Sage, 2004; Osborne and Beerling, 2006; Zhu et al., 2008). Our values fell within the range of $L E_{\max }$ reported for African savannas, which have varied from as low as $0.33 \mathrm{~g} \mathrm{C} \mathrm{MJ}^{-1} \mathrm{PAR}^{-1}$ up to $3.5 \mathrm{~g} \mathrm{C} \mathrm{MJ}^{-1} \mathrm{PAR}^{-1}$ depending on the vegetation and season (Sjöström et al., 2013; Tagesson et al., 2015). Recent work has shown the importance of correctly applying $\mathrm{LUE}_{\max }$ values to $\mathrm{C}_{3}$ and $\mathrm{C}_{4}$ plants when using LUE models to calculate GPP (Yan et al., 2015). Therefore, to account for the $C_{3}: C_{4}$ differences, we applied these site and trait specific values to the LUE model used to estimate GPP. 

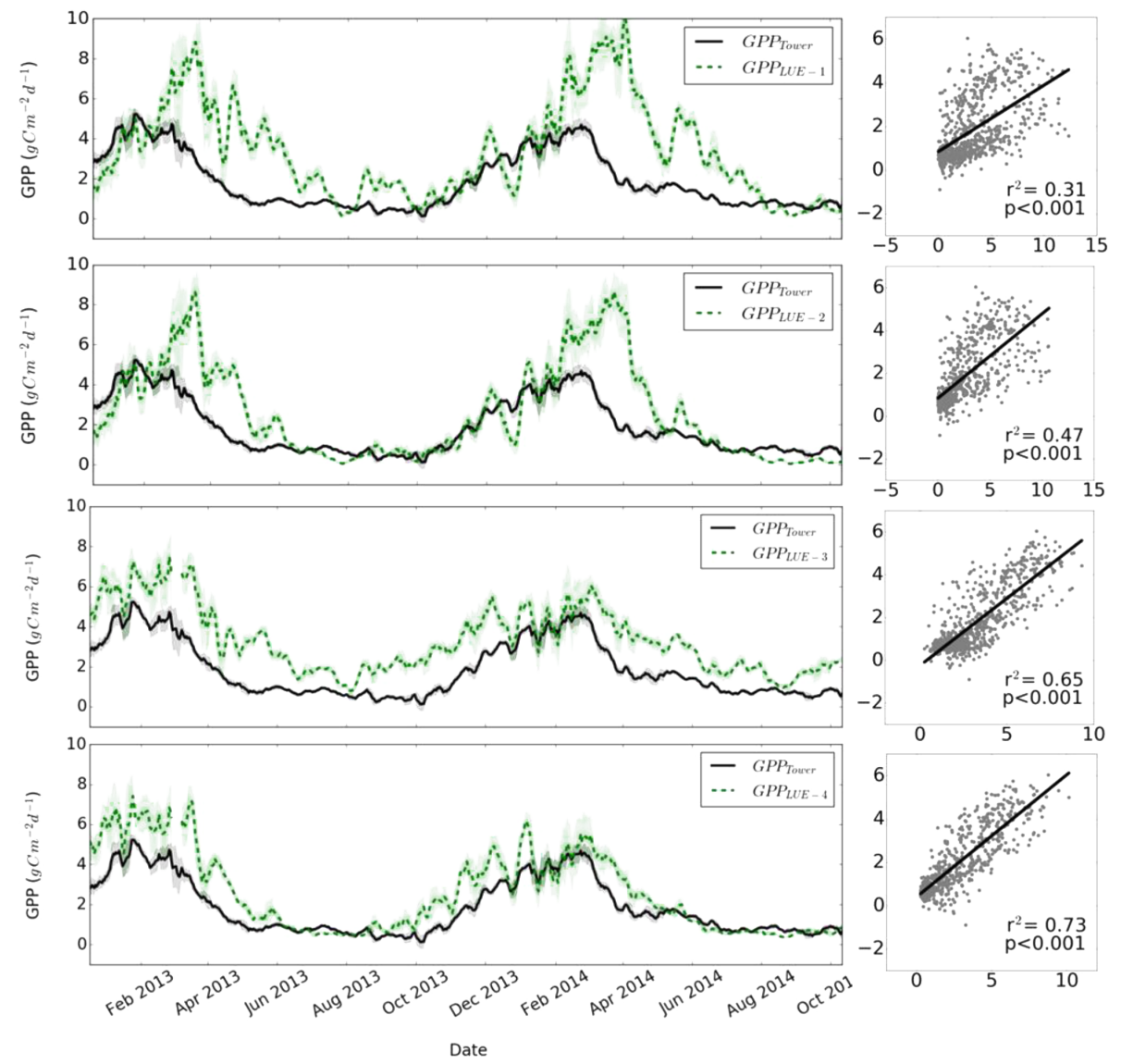

Figure 9. Understory flux tower estimated GPP with model predicted GPP for the Howard Springs OzFlux site. Models shown are (a) light use efficiency (LUE-1), (b) LUE with evaporative fraction (LUE-2), (c) LUE with green chromatic coordinates (LUE-3) and (d) LUE with EF and GCC (LUE-4).

The next step in our parameterisation of the LUE model was to test it in its traditional form, using the meteorological inputs of $T_{\mathrm{MIN}}$ and VPD that constrain $\mathrm{LUE}_{\max }$, along with APAR (Eq. 6). We found the model captured most of the seasonality of overstory GPP but underestimated the magnitude of GPP in the dry season and overestimated GPP in the wet season (Table 2, Fig. 8a). For the understory, the LUE model appeared to overestimate and lag flux tower GPP consistently by $1-2$ months (Table 2, Fig. 9 a). This resulted in a strong dry season overestimate of understory GPP $(165 \%$, Table 2). For the ecosystem, the LUE model consistently overestimated GPP (Table 2, Fig. 10a). Kanniah et al. (2009) also found the LUE model performed poorly for the Howard Springs ecosystem, so they replaced the standard VPD parameterisation with an EF term and found this to improve the relationship, which we implemented next.

The EF value improved model predictions of overstory GPP in the dry season but overestimated GPP in the wet season, causing an overprediction of annual GPP by $18 \%$ overall (Table 2, Fig. 8a vs. b). In contrast, the inclusion of EF in the understory LUE model slightly improved the prediction of annual GPP, with better correlation (0.69 vs. 0.56), lower RMSE (2.00 vs. $2.66 \mathrm{~g} \mathrm{C} \mathrm{m}^{-2}$ ) and lower RPE (38.58 vs. $79.62 \%)$. However, the understory model still lagged tower GPP and was still particularly poor at capturing the seasonal transitions (Fig. 9a, b). For the ecosystem, the inclusion of EF enhanced the overestimation of GPP from 15 to $26 \%$, particularly in the wet season (Table 2, Fig. 10a vs. b). EF provides a proxy measure of soil moisture as it includes a water flux component (LE) that is tightly linked with soil moisture availability (Gentine et al., 2007; Kanniah et al., 2009). In Australian savannas, soil moisture is highly seasonal and a major driver of productivity (Kanniah et al., 2010). This makes EF a useful index in the dry season, when latent heat largely comes from transpiration and is therefore tightly coupled with GPP. However, in the wet season, soil evaporation contributes a large amount to latent heat, which is not tightly coupled to GPP (Kanniah et al., 2009). This explains why EF is able to constrain the LUE model in the dry season and why it performs poorly in the wet season and transition periods.

Despite the improvements of EF, the model still performed poorly at capturing the wet-dry-wet season transition pe- 

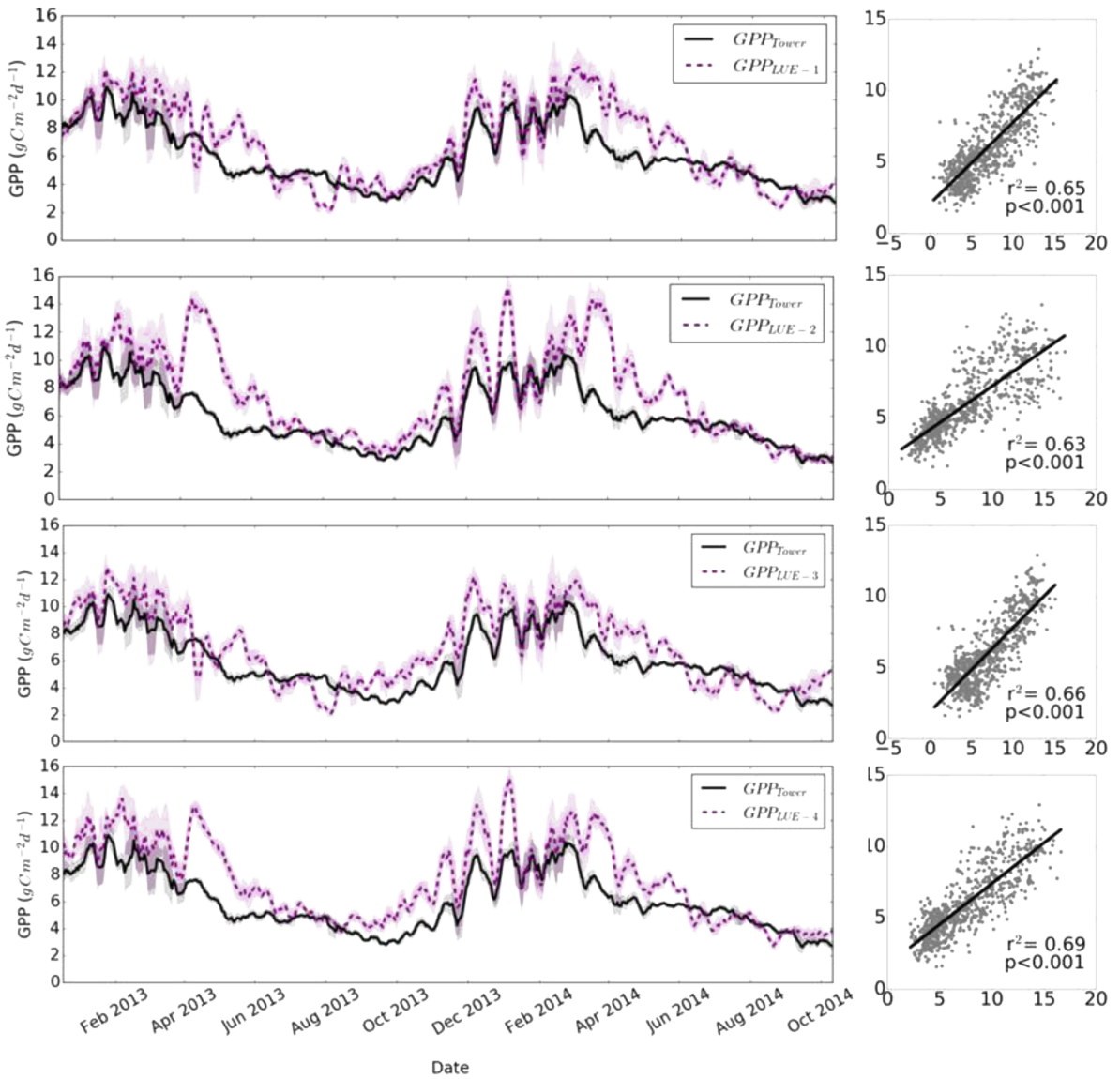

Figure 10. Ecosystem flux tower estimated GPP with model predicted GPP for the Howard Springs OzFlux site. Models shown are (a) light use efficiency (LUE-1), (b) LUE with evaporative fraction (EF, LUE-2), (c) LUE with MODIS enhanced vegetation index (EVI, LUE-3) and (d) LUE with EF and EVI (LUE-4).

Table 2. Summary of model performances against flux tower estimated GPP for overstory and understory at Howard Springs. Statistics include the Pearson correlation coefficient (Corr), the root mean square error (RMSE, $\mathrm{g} \mathrm{C} \mathrm{m}^{-2} \mathrm{~d}^{-1}$ ) and the relative predictive error (RPE, $\%$ ) for the light use efficiency model (LUE), LUE with evaporative fraction (LUE_EF), LUE with green chromatic coordinates (LUE_GCC) and LUE with EF and GCC (LUE_EF_GCC). Pearson $p$ values are not included as all were significant with $P<0.001$.

\begin{tabular}{ll|rrr|rrr|rrr|rr}
\hline & & \multicolumn{3}{|c|}{ Overstory } & \multicolumn{3}{c|}{ Understory } & \multicolumn{3}{c}{ Ecosystem* } \\
\cline { 3 - 9 } & Model & Corr & RMSE & RPE & Corr & RMSE & RPE & Corr & RMSE & RPE \\
\hline \multirow{2}{*}{ All years } & LUE & 0.64 & 1.64 & 7.50 & 0.56 & 2.66 & 79.62 & 0.80 & 2.18 & 14.82 \\
& LUE_EF & 0.73 & 1.80 & 18.33 & 0.69 & 2.00 & 38.58 & 0.79 & 2.79 & 26.39 \\
& LUE_GCC/EVI* & 0.60 & 1.56 & 6.39 & 0.81 & 1.86 & 80.21 & 0.81 & 2.12 & 15.49 \\
& LUE_EF_GCC/EVI* & 0.72 & 1.60 & 16.38 & 0.86 & 1.42 & 39.59 & 0.83 & 2.52 & 26.22 \\
\hline Wet season & LUE & 0.61 & 2.00 & 24.51 & 0.31 & 3.20 & 52.00 & 0.72 & 2.54 & 16.97 \\
(15 Oct-15 Apr) & LUE_EF & 0.68 & 2.37 & 34.93 & 0.39 & 2.73 & 41.09 & 0.66 & 3.32 & 26.83 \\
& LUE_GCC/EVI* & 0.61 & 1.78 & 22.52 & 0.63 & 2.16 & 53.83 & 0.74 & 2.46 & 19.63 \\
& LUE_EF_GCC/EVI* & 0.69 & 2.06 & 32.40 & 0.67 & 1.97 & 45.18 & 0.71 & 3.13 & 29.12 \\
\hline Dry season & LUE & 0.40 & 1.26 & -10.75 & 0.56 & 2.09 & 165.76 & 0.57 & 1.83 & 11.71 \\
(16 Apr-14 Oct) & LUE_EF & 0.64 & 1.12 & 0.51 & 0.52 & 1.05 & 30.77 & 0.72 & 2.26 & 25.75 \\
& LUE_GCC/EVI* & 0.23 & 1.34 & -10.91 & 0.45 & 1.55 & 162.43 & 0.39 & 1.77 & 9.51 \\
& LUE_EF_GCC/EVI* & 0.56 & 1.06 & -0.81 & 0.35 & 0.69 & 22.17 & 0.63 & 1.86 & 22.01 \\
\hline
\end{tabular}

The * highlights that the MODIS enhanced vegetation index (EVI) is used instead of GCC for the ecosystem analysis. 
riods. We believed this was due to APAR, which failed to capture the same degree of seasonality as the phenocam indexes (see Supplement). The incorporation of phenocam GCC into the LUE model improved the estimate of understory GPP substantially (Table 2, Fig. 9c, d). This was most apparent with the combined use of GCC and EF in the LUE model, which produced the best correlation $(r=0.86)$, lowest RMSE (1.42 $\mathrm{g} \mathrm{C} \mathrm{m}^{-2}$ ) and lowest RPE (39.59\%; Table 2, Fig. 9). These results show that while EF is an important factor for GPP, greenness phenology is also key for estimating understory productivity. In further support of this, the inclusion of GCC also eliminated the lag in model estimated GPP, bringing the estimate closer in line with seasonal variability from the flux tower, as evidenced by the large decrease in RMSE and RPE (Table 2, Fig. 9). As previously discussed, the understory grasses (annual species in particular) die off at the cessation of the wet season and do not contribute to the small fraction of understory GPP in the dry season (Moore et al., 2016a). This is a plant phenology response rather than a response to meteorological conditions, as factors such as soil moisture remain high enough in the early dry season to support plant growth (Eamus et al., 2002; Kelley et al., 2007; Moore et al., 2016a). Given that these grasses dominate understory biomass at Howard Springs, it is not surprising that including greenness phenology information in the LUE model improves its output relative to the flux tower.

The inclusion of greenness indices in the LUE model for the overstory (GCC) and ecosystem (EVI) also improved the estimate of GPP. For the overstory, the combination of EF and GCC performed slightly better in the dry season than GCC alone but was not able to capture the wet season well (Table 2, Fig. 8d). This resulted in the incorporation of GCC into the LUE model producing the best overall result despite the slightly lower correlation value ( 0.60 vs. 0.72 ) when compared with GCC and EF combined (Table 2). For the ecosystem, the inclusion of EVI into the LUE model performed the best at predicting GPP, which was supported by the lowest values for RMSE $\left(2.12 \mathrm{~g} \mathrm{C} \mathrm{m}^{-2}\right)$ and RPE $(15.49 \%$, Table 2).

The greenness information clearly fills an important gap in relation to changes in overstory, understory and ecosystem greenness. The general improvement in LUE model output for overstory, understory and ecosystem with the inclusion of greenness phenology information highlights the importance of accounting for phenological variability when estimating GPP in savannas. A similar result was found for a subalpine grassland in Italy, where phenocam greenness indices improved the ability of the same LUE model to predict grassland GPP (Migliavacca et al., 2011). Likewise, in an evergreen Amazonian rainforest, Wu et al. (2016) linked phenological changes in leaf development and demography to seasonality in GPP, showing the importance of phenology as a driver of ecosystem productivity. For Australian savannas, the effect of phenology is most evident at the end of the wet season (April-May), where growth in the understory ceases due to annual grass senescence even though meteorological conditions (temperature, VPD and/or EF) are still sufficient to support growth (Fig. 9a, b vs. c, d). The original LUE model overpredicts GPP as a result of this, which is due to APAR remaining high despite the lack of green vegetation (see Supplement). This effect is substantially reduced by the inclusion of greenness phenology indices that likely represents a type of "green APAR" that more closely tracks the vegetation productivity over time.

\subsection{Limitations, impacts and further work}

While phenocams have consistently proven to be a useful tool for phenological and productivity research (Richardson et al., 2009b; Migliavacca et al., 2011; Toomey et al., 2015; Wu et al., 2016), there still remain several limitations that require further investigation to improve their utility. Issues related to camera choice and image collection have been shown to be less problematic for simple identification of phenological transition dates and seasonal variation than first thought (Sonnentag et al., 2012); however, maintaining similar protocols for cross site comparisons remains preferable (Moore et al., 2016b). Scene illumination variability is probably the most problematic limitation of phenocams, which can be reduced by using chromatic coordinates or excess values, as well as by setting the white balance to a fixed level (Richardson et al., 2009a; Ide and Oguma, 2010; Migliavacca et al., 2011). Although white balance was not fixed for this study, we found that the GCC and ExG time series matched well with GPP estimates regardless, particularly once smoothed to an 8-day running mean time series to coincide with MODIS EVI data. Despite the AWB limitation, the GCC data provided added value to that gained from using just APAR alone in the LUE model, as also supported by the similar response in using EVI at the ecosystem level. We suspect this is due to the highly dynamic nature of the savanna vegetation, which allows the phenology signals to be identified despite the potential for variable white balance.

The wet season influence on scene illumination adds daily noise to the time series, but the indices are still useful for informing seasonal productivity estimates. This same relationship will likely not stand for other, less dynamic ecosystems in Australia (Restrepo-Coupe et al., 2016; Moore et al., 2016b), so we recommend the fixing of white balance where appropriate. The use of a grey reference panel for normalising phenocam images has also been proposed (Richardson et al., 2009a), but this technique has issues related to panel orientation and illumination conditions that can be different to those experienced by the phenocams (Migliavacca et al., 2011). Despite these limitations, phenocams are still an important tool for both species and plot-scale phenology monitoring and, with further developments, will continue to provide valuable insight into Australian vegetation phenology (Moore et al., 2016b). 
In addition to the phenocam issues, the light use efficiency model used in this study is also subject to limitations. This model relies on the input of meteorological information to generate an estimate of ecosystem GPP. It is often found that these models overestimate GPP in the transition periods from wet-dry or dry-wet in savanna ecosystems (Kanniah et al., 2009). The primary reason for this is that savanna GPP is not driven solely by meteorology and plant phenology also plays an important role, as shown in our analysis. The technique for estimating $\mathrm{LUE}_{\max }$, used in the LUE model (Eq. 5), also involves a degree of uncertainty that is centred around the input parameters of LUE and APAR, as well as the scalars used to constrain it (De Bie et al., 1998; Sjöström et al., 2013).

The MODIS MOD17 A2 GPP product uses a LUE $\max$ value of $1.21 \mathrm{~g} \mathrm{C} \mathrm{MJ}^{-1}$ for savannas and $1.24 \mathrm{~g} \mathrm{C} \mathrm{MJ}^{-1}$ for woody savannas (Zhao and Running, 2010). While these values are close to the number we calculated for the overstory $\left(1.43 \pm 0.06 \mathrm{~g} \mathrm{C} \mathrm{MJ}^{-1} \mathrm{PAR}^{-1}\right)$, we found the understory LUE $_{\text {max }}$ to be much larger $\left(3.45 \pm 0.41 \mathrm{~g} \mathrm{C} \mathrm{MJ}^{-1} \mathrm{PAR}^{-1}\right)$. Similarly, for African savannas, LUE $_{\max }$ has been found to reach up to $3.50 \mathrm{~g} \mathrm{C} \mathrm{MJ}^{-1} \mathrm{PAR}^{-1}$ in the wet (growing) season (Sjöström et al., 2013; Tagesson et al., 2015). These LUE $_{\text {max }}$ values are much larger than that used in the MOD17 A2 algorithm, which suggests that tree : grass $\left(\mathrm{C}_{3}\right.$ vs. $\left.\mathrm{C}_{4}\right)$ ratios need to be better accounted for in the LUE model. Recent work from Yan et al. (2015) has shown this to be the case, where the application of different $\mathrm{LUE}_{\max }$ values to $\mathrm{C}_{3}$ $\left(1.8 \mathrm{~g} \mathrm{C} \mathrm{MJ}^{-1} \mathrm{PAR}^{-1}\right)$ and $\mathrm{C}_{4}\left(2.76 \mathrm{~g} \mathrm{C} \mathrm{MJ}^{-1} \mathrm{PAR}^{-1}\right)$ plants improved global model estimates of GPP.

Finally, the flux tower estimates of GPP are not without their own limitations, as the towers measure NEE that is then partitioned into GPP and respiration most commonly by using a friction velocity $\left(u^{*}\right)$ threshold at night and upscaling method for the daytime (Reichstein et al., 2005; Bowman, 2000; Keith et al., 2012). Use of the $u^{*}$ technique has been shown to be problematic at sites with complex terrain (van Gorsel et al., 2009), where drainage flows result in horizontal loss of carbon from an ecosystem that is not accounted for by the flux instruments. While Howard Springs is a relatively flat site (slope $<1^{\circ}$ ) that should prevent issues with using the $u^{*}$ technique, the flux tower estimates from this site should still be considered with an amount of uncertainty as well (Moore et al., 2016a). However, these issues have been addressed by previous work at this site (Moore et al., 2016a) so we have confidence in the fluxes used for this study. Despite these limitations, we were able to show that the input of phenological information into LUE models can provide a useful constraint for estimating GPP within the uncertainty limits of tower-derived estimates, a similar conclusion to that found over a subalpine grassland in the Italian Alps (Migliavacca et al., 2011).

\section{Conclusions}

We have shown the utility of phenocams for the monitoring of tree and grass phenology in savannas and how these data can improve the quantification of productivity. Phenocams offer the ability to decipher species level phenological signals, as shown by our time series analysis of understory grasses and woody green species, as well as in the tracking of seasonal overstory leaf area change. Phenocams have also shown to be useful for improving LUE models that have traditionally failed to capture the wet-dry season transition periods well in savannas, which are characterised by phenology changes in the understory that are out of sync with meteorological variability. This approach needs to be tested in more ecosystems to determine its applicability for a wider range of ecosystem types, but it promises improved results for better understanding of ecosystem GPP and phenology. Phenological information offers an important link for our understanding of ecosystem function as it provides a more accurate means of independently verifying tower-derived GPP estimates in savannas. We have demonstrated that phenocams can be used in conjunction with eddy covariance flux towers to improve current knowledge of savanna productivity and phenology, which will assist in our understanding of how the tree-grass relationship in savannas may alter in the future.

\section{Data availability}

The eddy covariance data used in this manuscript are freely available from the OzFlux data portal (http://ozflux.org.au). The Howard Springs main tower data are provided by Beringer (2013a) and the understory data are provided by Beringer (2013b). The phenocam data will soon be freely available on the Australian Phenocam Network (https:// phenocam.org.au), or via contact with the corresponding author.

\section{The Supplement related to this article is available online at doi:10.5194/bg-14-111-2017-supplement.}

Author contributions. Field work and experimental design was executed by Caitlin E. Moore, Jason Beringer, Lindsay B. Hutley and Bradley Evans. Data analysis was chiefly carried out by C. Moore, with some coding assistance from Bradley Evans. The manuscript was prepared by Caitlin E. Moore with contributions from all coauthors.

Acknowledgements. Firstly, the authors would like to acknowledge support and funding from OzFlux and the overarching Terrestrial Ecosystem Research Network (TERN), which is supported by 
the Australian Government through the National Collaborative Research Infrastructure Strategy. This work utilised data collected by grants funded by the Australian Research Council (DP0344744, DP0772981 and DP130101566). Beringer is funded under an ARC FT (FT110100602). Bradley Evans is funded by the TERN Ecosystem Modelling and Scaling Infrastructure. Special thanks are also made to Dr Peter Isaac for his development of the OzFluxQC standardised processing tools and to Matthew Northwood for his design and building of the mini towers and for his assistance with field work.

Edited by: M. Migliavacca

Reviewed by: three anonymous referees

\section{References}

Andrew, M. H., and Mott, J. J.: Annuals with transient seed banks: the population biology of indigenous Sorghum species of tropical north-west Australia, Aust. J. Ecol., 8, 265-276, 1983.

Baldocchi, D., Falge, E., Gu, L., Olson, R., Hollinger, D., Running, S., Anthoni, P., Bernhofer, C., Davis, K., Evans, R., Fuentes, J., Goldstein, A., Katul, G., Law, B., Lee, X., Malhi, Y., Meyers, T., Munger, W., Oechel, W., Paw, U. K. T., Pilegaard, K., Schmid, H. P., Valentini, R., Verma, S., Vesala, T., Wilson, K., and Wofsy, S.: FLUXNET: A New Tool to Study the Temporal and Spatial Variability of Ecosystem-Scale Carbon Dioxide, Water Vapor, and Energy Flux Densities, Bull. Am. Meteorol. Soc., 82, 2415-2434, 2001.

Baret, F., de Solan, B., Lopez-Lozano, R., Ma, K., and Weiss, M.: GAI estimates of row crops from downward looking digital photos taken perpendicular to rows at $57.5^{\circ}$ zenith angle: Theoretical considerations based on 3D architecture models and application to wheat crops, Agr. Forest Meteorol., 150, 1393-1401, doi:10.1016/j.agrformet.2010.04.011, 2010.

Beringer, J., Hutley, L. B., Tapper, N. J., and Cernusak, L. A.: Savanna fires and their impact on net ecosystem productivity in North Australia, Glob. Change Biol., 13, 990-1004, 2007.

Beringer, J.: Howard Springs OzFlux tower site OzFlux: Australian and New Zealand Flux Research and Monitoring, hdl:102.100.100/14234, 2013a.

Beringer, J.: Howard Springs Understory OzFlux tower site OzFlux: Australian and New Zealand Flux Research and Monitoring, hdl: 102.100.100/14240, 2013b.

Beringer, J., Hutley, L. B., Abramson, D., Arndt, S. K., Briggs, P., Bristow, M., Canadell, J. G., Cernusak, L. A., Eamus, D., Edwards, A. C., Evans, B. J., Fest, B., Goergen, K., Grover, S. P., Hacker, J., Haverd, V., Kanniah, K., Livesley, S. J., Lynch, A., Maier, S., Moore, C., Raupach, M., Russell-Smith, J., Scheiter, S., Tapper, N. J., and Uotila, P.: Fire in Australian savannas: From leaf to landscape, Glob. Change Biol., 21, 62-81, doi:10.1111/gcb.12686, 2015.

Beringer, J., Hutley, L. B., McHugh, I., Arndt, S. K., Campbell, D., Cleugh, H. A., Cleverly, J., Resco de Dios, V., Eamus, D., Evans, B., Ewenz, C., Grace, P., Griebel, A., Haverd, V., Hinko-Najera, N., Huete, A., Isaac, P., Kanniah, K., Leuning, R., Liddell, M. J., Macfarlane, C., Meyer, W., Moore, C., Pendall, E., Phillips, A., Phillips, R. L., Prober, S. M., Restrepo-Coupe, N., Rutledge, S., Schroder, I., Silberstein, R., Southall, P., Yee, M. S., Tapper, N. J., van Gorsel, E., Vote, C., Walker, J., and Wardlaw, T.: An introduction to the Australian and New Zealand flux tower network - OzFlux, Biogeosciences, 13, 5895-5916, doi:10.5194/bg-135895-2016, 2016a.

Beringer, J., McHugh, I., Hutley, L. B., Isaac, P., and Kljun, N.: Dynamic INtegrated Gap-filling and partitioning for OzFlux (DINGO), Biogeosciences Discuss., doi:10.5194/bg-2016-188, in review, 2016b.

Bond, W. J.: What limits trees in $\mathrm{C}_{4}$ grasslands and savannas?, Annu. Rev. Ecol. Evol. S., 39, 641-659, 2008.

Bond, W. J., Midgley, G. F., and Woodward, F. I.: The importance of low atmospheric $\mathrm{CO}_{2}$ and fire in promoting the spread of grasslands and savannas, Glob. Change Biol., 9, 973-982, 2003.

Bowman, D. M. J. S.: Australian Rainforests : Islands of Green in a Land of Fire, Cambridge University Press, Cambridge, 2000.

Bowman, D. M. J. S. and Prior, L. D.: Why do evergreen trees dominate the Australian seasonal tropics?, Aust. J. Bot., 53, 379-399, 2005.

Broich, M., Huete, A., Paget, M., Ma, X., Tulbure, M., Coupe, N. R., Evans, B., Beringer, J., Devadas, R., Davies, K., and Held, A.: A spatially explicit land surface phenology data product for science, monitoring and natural resources management applications, Environ. Modell. Softw., 64, 191-204, doi:10.1016/j.envsoft.2014.11.017, 2015.

Brown, T. B., Hultine, K. R., Steltzer, H., Denny, E. G., Denslow, M. W., Granados, J., Henderson, S., Moore, D., Nagai, S., Sanclements, M., Sánchez-Azofeifa, A., Sonnentag, O., Tazik, D., and Richardson, A. D.: Using phenocams to monitor our changing earth: Toward a global phenocam network, Front. Ecol. Environ., 14, 84-93, doi:10.1002/fee.1222, 2016.

Cernusak, L. A., Hutley, L. B., Beringer, J., and Tapper, N. J.: Stem and leaf gas exchange and their responses to fire in a north Australian tropical savanna, Plant Cell Environ., 29, 632-646, 2006.

Chen, X., Eamus, D., and Hutley, L. B.: Seasonal patterns of soil carbon dioxide efflux from a wet-dry tropical savanna of northern Australia, Aust. J. Bot., 50, 43-51, doi:10.1071/BT01049, 2002.

Chen, X., Hutley, L. B., and Eamus, D.: Carbon balance of a tropical savanna of northern Australia, Oecologia, 137, 405-416, 2003.

Cook, G. D. and Heerdegen, R. G.: Spatial variation in the duration of the rainy season in monsoonal Australia, Int. J. Climatol., 21, 1723-1732, 2001.

Cook, G. D., Williams, R. J., Hutley, L. B., O'Grady, A. P., and Liedloff, A. C.: Variation in vegetative water use in the savannas of the North Australian Tropical Transect, J. Veg. Sci., 13, 413418, 2002.

Coops, N. C., Black, T. A., Jassal, R. S., Trofymow, J. A., and Morgenstern, K.: Comparison of MODIS, eddy covariance determined and physiologically modelled gross primary production (GPP) in a Douglas-fir forest stand, Remote Sens. Environ., 107, 385-401, doi:10.1016/j.rse.2006.09.010, 2007.

De Bie, S., Ketner, P., Paasse, M., and Geerling, C.: Woody plant phenology in the West Africa savanna, J. Biogeogr., 25, 883-900, doi:10.1046/j.1365-2699.1998.00229.x, 1998.

Eamus, D., Myers, B., Duff, G., and Williams, D.: Seasonal changes in photosynthesis of eight savanna tree species, Tree Physiol., 19, 665-671, 1999.

Eamus, D., Hutley, L. B., and O'Grady, A. P.: Daily and seasonal patterns of carbon and water fluxes above a north Australian savanna, Tree Physiol., 21, 977-988, 2001. 
Eamus, D., Chen, X., Kelley, G., and Hutley, L. B.: Root biomass and root fractal analyses of an open Eucalyptus forest in a savanna of north Australia, Aust. J. Bot., 50, 31-41, doi:10.1071/BT01054, 2002.

Eberhardt, I. D. R., Schultz, B., Rizzi, R., Sanches, I. D., Formaggio, A. R., Atzberger, C., Mello, M. P., Immitzer, M., Trabaquini, K., Foschiera, W., and Luiz, A. J. B.: Cloud cover assessment for operational crop monitoring systems in tropical areas, Remote Sens., 8, 1-14, doi:10.3390/rs8030219, 2016.

Gentine, P., Entekhabi, D., Chehbouni, A., Boulet, G., and Duchemin, B.: Analysis of evaporative fraction diurnal behaviour, Agr. Forest Meteorol., 143, 13-29, doi:10.1016/j.agrformet.2006.11.002, 2007.

Gillespie, A. R., Kahle, A. B., and Walker, R. E.: Color enhancement of highly correlated images, II. Channel ratio and "chromaticity" transformation techniques, Remote Sens. Environ., 22, 343-365, 1987.

Grace, J., José, J. S., Meir, P., Miranda, H. S., and Montes, R. A.: Productivity and carbon fluxes of tropical savannas, J. Biogeogr., 33, 387-400, 2006.

Hanan, N. P. and Lehmann, C. E. R.: Tree-Grass interactions in savannas: Paradigms, contradictions and conceptual models, in: Ecosystem Function in Savannas, edited by: Hill, M. J. and Hanan, N. P., CRC Press, Florida, 2010.

Hoch, W. A., Zeldin, E. L., and McCown, B. H.: Physiological significance of anthocyanins during autumnal leaf senescence, Tree Physiol., 21, 1-8, 2001.

Hoffmann, W. A., Geiger, E. L., Gotsch, S. G., Rossatto, D. R., Silva, L. C. R., Lau, O. L., Haridasan, M., and Franco, A. C.: Ecological thresholds at the savanna-forest boundary: How plant traits, resources and fire govern the distribution of tropical biomes, Ecol. Lett., 15, 759-768, 2012.

Huete, A., Didan, K., Miura, T., Rodriguez, E. P., Gao, X., and Ferreira, L. G.: Overview of the radiometric and biophysical performance of the MODIS vegetation indices, Remote Sens. Environ., 83, 195-213, 2002.

Hufkens, K., Friedl, M., Sonnentag, O., Braswell, B. H., Milliman, T., and Richardson, A. D.: Linking near-surface and satellite remote sensing measurements of deciduous broadleaf forest phenology, Remote Sens. Environ., 117, 307-321, doi:10.1016/j.rse.2011.10.006, 2012.

Hutley, L. and Beringer, J.: Distrubance and climatic drivers of carbon dynamics of a north Australian tropical savanna, in: Ecosystem Function in Savannas: Measurements and Modelling at Landscape to Global Scales, edited by: Hill, M. J. and Hanan, N. P., CRC Press, Boca Raton, 57-75, 2011.

Hutley, L. B., O'Grady, A. P., and Eamus, D.: Evapotranspiration from eucalypt open-forest savanna of northern australia, Funct. Ecol., 14, 183-194, 2000.

Hutley, L. B., Beringer, J., Isaac, P. R., Hacker, J. M., and Cernusak, L. A.: A sub-continental scale living laboratory: Spatial patterns of savanna vegetation over a rainfall gradient in northern Australia, Agr. Forest Meteorol., 151, 1417-1428, 2011.

Hutley, L. B., Evans, B. J., Beringer, J., Cook, G. D., Maier, S. W., and Razon, E.: Impacts of an extreme cyclone event on landscape-scale savanna fire, productivity and greenhouse gas emissions, Environ. Res. Lett., 8, 1-12, 2013.
Ide, R. and Oguma, H.: Use of digital cameras for phenological observations, Ecol. Inform., 5, 339-347, doi:10.1016/j.ecoinf.2010.07.002, 2010.

Isbell, R. F.: The Australian Soil Classification, CSIRO Publishing, Collingwood, VIC, 1996.

Kaimal, J. C. and Finnigan, J. J.: Atmospheric boundary layer flows: their structure and measurement, Oxford University Press, New York, 1994.

Kanniah, K. D., Beringer, J., Hutley, L. B., Tapper, N. J., and Zhu, X.: Evaluation of Collections 4 and 5 of the MODIS Gross Primary Productivity product and algorithm improvement at a tropical savanna site in northern Australia, Remote Sens. Environ., 113, 1808-1822, 2009.

Kanniah, K. D., Beringer, J., and Hutley, L. B.: The comparative role of key environmental factors in determining savanna productivity and carbon fluxes: A review, with special reference to Northern Australia, Prog. Phys. Geog., 34, 459-490, doi:10.1177/0309133310364933, 2010.

Kanniah, K. D., Beringer, J., and Hutley, L. B.: Environmental controls on the spatial variability of savanna productivity in the Northern Territory, Australia, Agr. Forest Meteorol., 151, 14291439, 2011.

Keith, H., van Gorsel, E., Jacobsen, K. L., and Cleugh, H. A.: Dynamics of carbon exchange in a Eucalyptus forest in response to interacting disturbance factors, Agr. Forest Meteorol., 153, 6781, doi:10.1016/j.agrformet.2011.07.019, 2012.

Kelley, G., O’Grady, A. P., Hutley, L. B., and Eamus, D.: A comparison of tree water use in two contiguous vegetation communities of the seasonally dry tropics of northern Australia: The importance of site water budget to tree hydraulics, Aust. J. Bot., 55, 700-708, doi:10.1071/BT07021, 2007.

Lee, D. W., O'Keefe, J., Holbrook, N. M., and Feild, T. S.: Pigment dynamics and autumn leaf senescence in a New England deciduous forest, eastern USA, Ecol. Res., 18, 677-694, 2003.

Lehmann, C. E. R., Anderson, T. M., Sankaran, M., Higgins, S. I., Archibald, S., Hoffmann, W. A., Hanan, N. P., Williams, R. J., Fensham, R. J., Felfili, J., Hutley, L. B., Ratnam, J., San Jose, J., Montes, R., Franklin, D., Russell-Smith, J., Ryan, C. M., Durigan, G., Hiernaux, P., Haidar, R., Bowman, D. M. J. S., and Bond, W. J.: Savanna vegetation-fire-climate relationships differ among continents, Science, 343, 548-552, 2014.

Ma, X., Huete, A., Yu, Q., Coupe, N. R., Davies, K., Broich, M., Ratana, P., Beringer, J., Hutley, L. B., Cleverly, J., Boulain, N., and Eamus, D.: Spatial patterns and temporal dynamics in savanna vegetation phenology across the north australian tropical transect, Remote Sens. Environ., 139, 97-115, 2013.

Ma, X., Huete, A., Yu, Q., Restrepo-Coupe, N., Beringer, J., Hutley, L. B., Kanniah, K. D., Cleverly, J., and Eamus, D.: Parameterization of an ecosystem light-use-efficiency model for predicting savanna GPP using MODIS EVI, Remote Sens. Environ., 154, 253-271, doi:10.1016/j.rse.2014.08.025, 2014.

Migliavacca, M., Galvagno, M., Cremonese, E., Rossini, M., Meroni, M., Sonnentag, O., Cogliati, S., Manca, G., Diotri, F., Busetto, L., Cescatti, A., Colombo, R., Fava, F., Morra di Cella, U., Pari, E., Siniscalco, C., and Richardson, A. D.: Using digital repeat photography and eddy covariance data to model grassland phenology and photosynthetic $\mathrm{CO}_{2}$ uptake, Agr. Forest Meteorol., 151, 1325-1337, 2011. 
Monteith, J. L.: Solar Radiation and Productivity in Tropical Ecosystems, J. Appl. Ecol., 9, 747-766, doi:10.2307/2401901, 1972.

Moore, C. E., Beringer, J., Evans, B., Hutley, L. B., McHugh, I., and Tapper, N. J.: The contribution of trees and grasses to productivity of an Australian tropical savanna, Biogeosciences, 13, 2387-2403, doi:10.5194/bg-13-2387-2016, 2016 a.

Moore, C. E., Brown, T., Keenan, T. F., Duursma, R. A., van Dijk, A. I. J. M., Beringer, J., Culvenor, D., Evans, B., Huete, A., Hutley, L. B., Maier, S., Restrepo-Coupe, N., Sonnentag, O., Specht, A., Taylor, J. R., van Gorsel, E., and Liddell, M. J.: Reviews and syntheses: Australian vegetation phenology: new insights from satellite remote sensing and digital repeat photography, Biogeosciences, 13, 5085-5102, doi:10.5194/bg-13-5085-2016, $2016 \mathrm{~b}$.

Murphy, B. P., Russell-Smith, J., and Prior, L. D.: Frequent fires reduce tree growth in northern Australian savannas: Implications for tree demography and carbon sequestration, Glob. Change Biol., 16, 331-343, 2010.

Noormets, A.: Phenology of Ecosystem Processes, Springer, New York, 2009.

O’Grady, A. P., Eamus, D., and Hutley, L. B.: Transpiration increases during the dry season: Patterns of tree water use in eucalypt open-forests of northern Australia, Tree Physiol., 19, 591597, 1999.

O’Grady, A. P., Chen, X., Eamus, D., and Hutley, L. B.: Composition, leaf area index and standing biomass of eucalypt open forests near Darwin in the Northern Territory, Australia, Aust. J. Bot., 48, 629-638, 2000.

Osborne, C. P. and Beerling, D. J.: Nature's green revolution: The remarkable evolutionary rise of $\mathrm{C}_{4}$ plants, Philos. T. R. Soc. B, 361, 173-194, doi:10.1038/35075035, 2006.

Prior, L. D., Eamus, D., and Bowman, D. M. J. S.: Tree growth rates in north Australian savanna habitats: Seasonal patterns and correlations with leaf attributes, Aust. J. Bot., 52, 303-314, doi:10.1071/BT03119, 2004.

Ratnam, J., Bond, W. J., Fensham, R. J., Hoffmann, W. A., Archibald, S., Lehmann, C. E. R., Anderson, M. T., Higgins, S. I., and Sankaran, M.: When is a "forest" a savanna, and why does it matter?, Glob. Ecol. Biogeogr., 20, 653-660, 2011.

Reichstein, M., Falge, E., Baldocchi, D., Papale, D., Aubinet, M., Berbigier, P., Bernhofer, C., Buchmann, N., Gilmanov, T., Granier, A., Grünwald, T., Havránková, K., Ilvesniemi, H., Janous, D., Knohl, A., Laurila, T., Lohila, A., Loustau, D., Matteucci, G., Meyers, T., Miglietta, F., Ourcival, J. M., Pumpanen, J., Rambal, S., Rotenberg, E., Sanz, M., Tenhunen, J., Seufert, G., Vaccari, F., Vesala, T., Yakir, D., and Valentini, R.: On the separation of net ecosystem exchange into assimilation and ecosystem respiration: Review and improved algorithm, Glob. Change Biol., 11, 1424-1439, 2005.

Restrepo-Coupe, N., Huete, A., Davies, K., Cleverly, J., Beringer, J., Eamus, D., van Gorsel, E., Hutley, L. B., and Meyer, W. S.: MODIS vegetation products as proxies of photosynthetic potential along a gradient of meteorologically and biologically driven ecosystem productivity, Biogeosciences, 13, 5587-5608, doi:10.5194/bg-13-5587-2016, 2016.

Richardson, A. D., Jenkins, J. P., Braswell, B. H., Hollinger, D. Y., Ollinger, S. V., and Smith, M. L.: Use of digital webcam images to track spring green-up in a deciduous broadleaf forest, Oecologia, 152, 323-334, 2007.
Richardson, A. D., Braswell, B. H., Hollinger, D. Y., Jenkins, J. P., and Ollinger, S. V.: Near-surface remote sensing of spatial and temporal variation in canopy phenology, Ecol. Appl., 19, 14171428, 2009a.

Richardson, A. D., Hollinger, D. Y., Dail, D. B., Lee, J. T., Munger, J. W., and O'Keefe, J.: Influence of spring phenology on seasonal and annual carbon balance in two contrasting New England forests, Tree Physiol., 29, 321-331, 2009b.

Richardson, A. D., Black, T. A., Ciais, P., Delbart, N., Friedl, M. A., Gobron, N., Hollinger, D. Y., Kutsch, W. L., Longdoz, B., Luyssaert, S., Migliavacca, M., Montagnani, L., Munger, J. W., Moors, E., Piao, S., Rebmann, C., Reichstein, M., Saigusa, N., Tomelleri, E., Vargas, R., and Varlagin, A.: Influence of spring and autumn phenological transitions on forest ecosystem productivity, Philos. T. R. Soc. B, 365, 3227-3246, 2010.

Richardson, A. D., Keenan, T. F., Migliavacca, M., Ryu, Y., Sonnentag, O., and Toomey, M.: Climate change, phenology, and phenological control of vegetation feedbacks to the climate system, Agr. Forest Meteorol., 169, 156-173, 2013.

Rogers, C. and Beringer, J.: Describing rainfall in northern Australia using multiple climate indices, Biogeosciences Discuss., doi:10.5194/bg-2016-172, in review, 2016.

Running, S. W. and Zhao, M.: User's Guide: Daily GPP and annual NPP (MOD17 A2/A3) products, NASA Earth Observing System MODIS land algorithm 1-28, 2015.

Ryu, Y., Sonnentag, O., Nilson, T., Vargas, R., Kobayashi, H., Wenk, R., and Baldocchi, D. D.: How to quantify tree leaf area index in an open savanna ecosystem: A multi-instrument and multi-model approach, Agr. Forest Meteorol., 150, 63-76, doi:10.1016/j.agrformet.2009.08.007, 2010.

Ryu, Y., Baldocchi, D. D., Kobayashi, H., Van Ingen, C., Li, J., Black, T. A., Beringer, J., Van Gorsel, E., Knohl, A., Law, B. E., and Roupsard, O.: Integration of MODIS land and atmosphere products with a coupled-process model to estimate gross primary productivity and evapotranspiration from $1 \mathrm{~km}$ to global scales, Global Biogeochem. Cy., 25, 1-24, 2011.

Ryu, Y., Verfaillie, J., Macfarlane, C., Kobayashi, H., Sonnentag, O., Vargas, R., Ma, S., and Baldocchi, D. D.: Continuous observation of tree leaf area index at ecosystem scale using upwardpointing digital cameras, Remote Sens. Environ., 126, 116-125, doi:10.1016/j.rse.2012.08.027, 2012.

Sage, R. F.: The evolution of $\mathrm{C}_{4}$ photosynthesis, New Phytol., 161, 341-370, 2004.

Savitzky, A. and Golay, M. J. E.: Smoothing and differentiation of data by simplified least squares procedures, Anal. Chem., 36, 1627-1639, 1964.

Scheiter, S., Higgins, S. I., Beringer, J., and Hutley, L. B.: Climate change and long-term fire management impacts on Australian savannas, New Phytol., 205, 1211-1226, doi:10.1111/nph.13130, 2015.

Scholes, R. J. and Archer, S. R.: Tree-grass interactions in Savannas, Annu. Rev. Ecol. Syst., 28, 517-544, 1997.

Scott, K. A., Setterfield, S. A., Douglas, M. M., and Andersen, A. N.: Environmental factors influencing the establishment, height and fecundity of the annual grass Sorghum intrans in an Australian tropical savanna, J. Trop. Ecol., 26, 313-322, 2010.

Silva, I. A., Da Silva, D. M., De Carvalho, G. H., and Batalha, M. A.: Reproductive phenology of Brazilian savannas and riparian 
forests: Environmental and phylogenetic issues, Ann. Forest Sci., 68, 1207-1215, doi:10.1007/s13595-011-0071-5, 2011.

Sjöström, M., Zhao, M., Archibald, S., Arneth, A., Cappelaere, B., Falk, U., de Grandcourt, A., Hanan, N., Kergoat, L., Kutsch, W., Merbold, L., Mougin, E., Nickless, A., Nouvellon, Y., Scholes, R. J., Veenendaal, E. M., and Ardö, J.: Evaluation of MODIS gross primary productivity for Africa using eddy covariance data, Remote Sens. Environ., 131, 275-286, doi:10.1016/j.rse.2012.12.023, 2013.

Sonnentag, O., Hufkens, K., Teshera-Sterne, C., Young, A. M., Friedl, M., Braswell, B. H., Milliman, T., O'Keefe, J., and Richardson, A. D.: Digital repeat photography for phenological research in forest ecosystems, Agr. Forest Meteorol., 152, 159177,2012

Specht, R. L.: Vegetation, in: Australian Environment, 4 Edn., edited by: Leeper, G. W., Melbourne University Press, Melbourne, 44-67, 1972.

Tagesson, T., Fensholt, R., Cropley, F., Guiro, I., Horion, S., Ehammer, A., and Ardö, J.: Dynamics in carbon exchange fluxes for a grazed semi-arid savanna ecosystem in West Africa, Agr. Ecosys. Environ., 205, 15-24, doi:10.1016/j.agee.2015.02.017, 2015.

Toomey, M., Friedl, M. A., Frolking, S., Hufkens, K., Klosterman, S., Sonnentag, O., Baldocchi, D. D., Bernacchi, C. J., Biraud, S. C., Bohrer, G., Brzostek, E., Burns, S. P., Coursolle, C., Hollinger, D. Y., Margolis, H. A., McCaughey, H., Monson, R. K., Munger, J. W., Pallardy, S., Phillips, R. P., Torn, M. S., Wharton, S., Zeri, M., and Richardson, A. D.: Greenness indices from digital cameras predict the timing and seasonal dynamics of canopy-scale photosynthesis, Ecol. Appl., 25, 99-115, 2015.

Tucker, C. J.: Red and photographic infrared linear combinations for monitoring vegetation, Remote Sens. Environ., 8, 127-150, 1979.

van Gorsel, E., Delpierre, N., Leuning, R., Black, A., Munger, J. W., Wofsy, S., Aubinet, M., Feigenwinter, C., Beringer, J., Bonal, D., Chen, B., Chen, J., Clement, R., Davis, K. J., Desai, A. R., Dragoni, D., Etzold, S., Grünwald, T., Gu, L., Heinesch, B., Hutyra, L. R., Jans, W. W. P., Kutsch, W., Law, B. E., Leclerc, M. Y., Mammarella, I., Montagnani, L., Noormets, A., Rebmann, C., and Wharton, S.: Estimating nocturnal ecosystem respiration from the vertical turbulent flux and change in storage of $\mathrm{CO}_{2}, \mathrm{Agr}$. Forest Meteorol., 149, 1919-1930, 2009.

Van Langevelde, F., Van De Vijver, C. A. D. M., Kumar, L., Van De Koppel, J., De Ridder, N., Van Andel, J., Skidmore, A. K., Hearne, J. W., Stroosnijder, L., Bond, W. J., Prins, H. H. T., and Rietkerk, M.: Effects of fire and herbivory on the stability of savanna ecosystems, Ecology, 84, 337-350, 2003.

Weiss, M., Baret, F., Smith, G. J., Jonckheere, I., and Coppin, P.: Review of methods for in situ leaf area index (LAI) determination Part II, Estimation of LAI, errors and sampling, Agr. Forest Meteorol., 121, 37-53, 2004.

Werner, P. A. and Franklin, D. C.: Resprouting and mortality of juvenile eucalypts in an Australian savanna: Impacts of fire season and annual sorghum, Aust. J. Bot., 58, 619-628, doi:10.1071/BT10139, 2010.

Werner, P. A. and Prior, L. D.: Demography and growth of subadult savanna trees: Interactions of life history, size, fire season, and grassy understory, Ecol. Monogr., 83, 67-93, 2013.
Whitley, R. J., Macinnis-Ng, C. M. O., Hutley, L. B., Beringer, J., Zeppel, M., Williams, M., Taylor, D., and Eamus, D.: Is productivity of mesic savannas light limited or water limited? Results of a simulation study, Glob. Change Biol., 17, 3130-3149, doi:10.1016/j.agformet.2011.01.006, 2011.

Williams, R. J., Myers, B. A., Muller, W. J., Duff, G. A., and Eamus, D.: Leaf phenology of woody species in a North Australian tropical savanna, Ecology, 78, 2542-2558, 1997.

Wingate, L., Ogée, J., Cremonese, E., Filippa, G., Mizunuma, T., Migliavacca, M., Moisy, C., Wilkinson, M., Moureaux, C., Wohlfahrt, G., Hammerle, A., Hörtnagl, L., Gimeno, C., PorcarCastell, A., Galvagno, M., Nakaji, T., Morison, J., Kolle, O., Knohl, A., Kutsch, W., Kolari, P., Nikinmaa, E., Ibrom, A., Gielen, B., Eugster, W., Balzarolo, M., Papale, D., Klumpp, K., Köstner, B., Grünwald, T., Joffre, R., Ourcival, J.-M., Hellstrom, M., Lindroth, A., George, C., Longdoz, B., Genty, B., Levula, J., Heinesch, B., Sprintsin, M., Yakir, D., Manise, T., Guyon, D., Ahrends, H., Plaza-Aguilar, A., Guan, J. H., and Grace, J.: Interpreting canopy development and physiology using a European phenology camera network at flux sites, Biogeosciences, 12, 5995-6015, doi:10.5194/bg-12-5995-2015, 2015.

Woebbecke, D. M., Meyer, G. E., Von Bargen, K., and Mortensen, D. A.: Color indices for weed identification under various soil, residue, and lighting conditions, T. Am. Soc. Agr. Eng., 38, 259269, 1995.

Wu, J., Albert, L. P., Lopes, A. P., Restrepo-Coupe, N., Hayek, M., Wiedemann, K. T., Guan, K., Strark., S. C., Christoffersen, B., Prohaska, N., Tavares, J. V., Marostica, S., Kobayashi, H., Ferreira, M. L., Campos, K. S., da Silva, R., Brando, P. M., Dye, D. G., Huxman, T. E., Huete, A., Nelson, B. W., and Saleska, S. R.: Leaf development and demography explain photosynthetic seasonality in Amazon evergreen forests, Science, 351, 972-976, 2016.

Yan, H., Wang, S. Q., Billesbach, D., Oechel, W., Bohrer, G., Meyers, T., Martin, T. A., Matamala, R., Phillips, R. P., Rahman, F., Yu, Q., and Shugart, H. H.: Improved global simulations of gross primary product based on a new definition of water stress factor and a separate treatment of $\mathrm{C}_{3}$ and $\mathrm{C}_{4}$ plants, Ecol. Modell., 297, 42-59, doi:10.1016/j.ecolmodel.2014.11.002, 2015.

Yuan, W., Liu, S., Zhou, G., Zhou, G., Tieszen, L. L., Baldocchi, D., Bernhofer, C., Gholz, H., Goldstein, A. H., Goulden, M. L., Hollinger, D. Y., Hu, Y., Law, B. E., Stoy, P. C., Vesala, T., and Wofsy, S. C.: Deriving a light use efficiency model from eddy covariance flux data for predicting daily gross primary production across biomes, Agr. Forest Meteorol., 143, 189-207, doi:10.1016/j.agrformet.2006.12.001, 2007.

Zhao, M. and Running, S. W.: Drought-induced reduction in global terrestrial net primary production from 2000 through 2009, Science, 329, 940-943, doi:10.1126/science.1192666, 2010.

Zhu, X. G., Long, S. P., and Ort, D. R.: What is the maximum efficiency with which photosynthesis can convert solar energy into biomass?, Curr. Opin. Biotech., 19, 153-159, doi:10.1016/j.copbio.2008.02.004, 2008. 